San Jose State University

SJSU ScholarWorks

Master's Theses

Master's Theses and Graduate Research

1995

\title{
Attitudes of Vietnamese toward persons with physical disabilities as perceived by Vietnamese individuals with disability
}

Phuong-Trang Phan

San Jose State University

Follow this and additional works at: https://scholarworks.sjsu.edu/etd_theses

\section{Recommended Citation}

Phan, Phuong-Trang, "Attitudes of Vietnamese toward persons with physical disabilities as perceived by Vietnamese individuals with disability" (1995). Master's Theses. 1025.

DOI: https://doi.org/10.31979/etd.3p8w-8jhz

https://scholarworks.sjsu.edu/etd_theses/1025

This Thesis is brought to you for free and open access by the Master's Theses and Graduate Research at SJSU ScholarWorks. It has been accepted for inclusion in Master's Theses by an authorized administrator of SJSU ScholarWorks. For more information, please contact scholarworks@sjsu.edu. 


\section{INFORMATION TO USERS}

This manuscript has been reproduced from the microfilm master. UMI films the text directly from the original or copy submitted. Thus, some thesis and dissertation copies are in typewriter face, while others may be from any type of computer printer.

The quality of this reproduction is dependent upon the quality of the copy submitted. Broken or indistinct print, colored or poor quality illustrations and photographs, print bleedthrough, substandard margins, and improper alignment can adversely affect reproduction.

In the unlikely event that the author did not send UMI a complete manuscript and there are missing pages, these will be noted. Also, if unauthorized copyright material had to be removed, a note will indicate the deletion.

Oversize materials (e.g., maps, drawings, charts) are reproduced by sectioning the original, beginning at the upper left-hand corner and continuing from left to right in equal sections with small overlaps. Each original is also photographed in one exposure and is included in reduced form at the back of the book.

Photographs included in the original mamuscript have been reproduced xerographically in this copy. Higher quality $6^{n} \times 9^{n}$ black and white photographic prints are available for any photographs or illustrations appearing in this copy for an additional charge. Contact UMI directly to order.

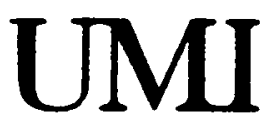

A Bell \& Howell Information Company 300 North Zeeb Road. Ann Arbor. MI 48106-1346 USA 313:761-4700 800:521-0600 



\section{ATTITUDES OF VIETNAMESE \\ TOWARD PERSONS WITH PHYSICAL DISABILITIES AS PERCEIVED BY VIETNAMESE INDIVIDUALS WITH DISABILITY}

A Thesis Presented to

The Faculty of the Department of Occupational Therapy

San Jose State University

In partial fulfillment

of the Requirements for the Degree

Master of Science

By

Phuong-Trang Phan

May, 1995 
JMI Number: 1374616

UMI Microform 1374616

Copyright 1995, by OMI Company. All rights reserved.

This microform edition is protected against unauthorized copying under Title 17, United States Code.

\section{UMI}

300 North Zeeb Road

Ann Arbor, MI 48103 
(C) 1995

Phuong-Trang Phan

ALL RIGHTS RESERVED 

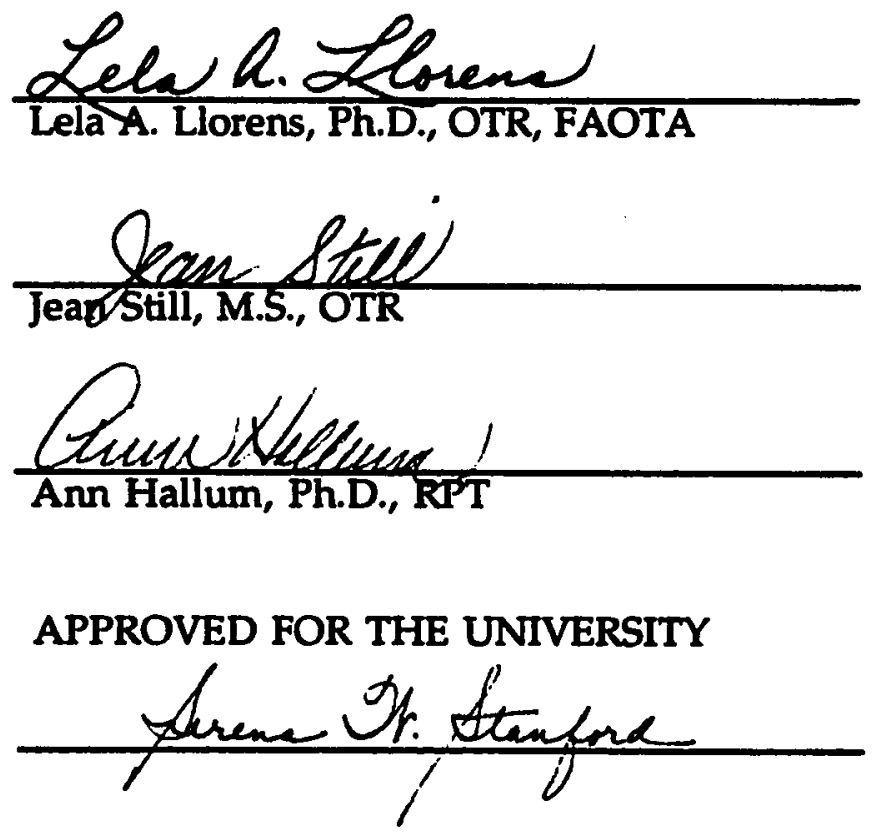


\begin{abstract}
ATTITUDES OF VIETNAMESE

TOWARD PERSONS WITH PHYSICAL DISABILITIES

AS PERCEIVED BY VIETNAMESE DISABLED INDIVIDUALS
\end{abstract}

By Phuong-Trang Phan

This study examined how Vietnamese persons with disabilities perceive (1) the attitudes of family members (i.e. parents, siblings, spouse) toward persons with disabilities, and (2) the attitudes of non-family members (i.e. friends, co-workers, general public) toward persons with disabilities. The study also explored the disabled persons' attitudes about disabilities and the motivational factors that they use in psychosocial adjustment and selfimprovement.

Six Vietnamese participants, who are physically disabled and presently residing in the United States, participated in in-depth interviews conducted in either Vietnamese or English. The transcribed interviews were qualitatively analyzed, and synthesized to identify recurring themes. Themes identified indicate that family members have attitudes of loving, protectiveness, and are conservative in their expectations toward the member with a disability. Vietnamese people in the United States showed increased awareness regarding disabilities and behave either indifferently or helpfully toward persons with disabilities. Participants expressed the belief that persons with disabilities are capable and are contributors of society. Motivational factors included love from others, personal needs, social opportunities, and role models. 


\section{ACKNOWLEDGEMENTS}

I would like to express sincere gratitude and appreciation to all of the people who assisted with the completion of this study.

Thank you to my thesis committee members, Dr. Lela Llorens, Associate Professor Jean Still, and Dr. Ann Hallum, for their guidance, careful editing, and patience.

Thank you to my "unofficial reader," Mimi Nguyen. Your input and cultural sensitivity are valuable. Thanks for the brainstorming sessions and for having faith in me.

Thank you to my father, Mr. Co Phan, and my brother-in-law, Viet Nguyen, for the assistance with language translation. Special thanks to Viet for computer advice.

Thank you to all of the staff members at Poplar Center for their support and encouragement throughout the process of completing this thesis. Special thanks go to Vicki Vavuris for the endless proofreading.

Many thanks to my family, respected elders, and friends who assisted me wholeheartedly in my journey to find participants.

I would like to especially thank the people who participated in this study. Thank you for sharing your lives and your personal thoughts with me despite of any initial reservations you may have. Without you, this study would not have been possible. 
Abstract

Acknowledgements $\quad$ V

List of Tables ix

CHAPTER ONE: INTRODUCTION 1

Purpose 1

$\begin{array}{ll}\text { Statement of the Problem } & 1\end{array}$

Research Questions 3

Definitions 3

Assumptions

Limitations 5

$\begin{array}{ll}\text { Significance of the Study } & 7\end{array}$

CHAPTER TWO: LITERATURE REVIEW 10

$\begin{array}{ll}\text { Southeast Asian and Vietnamese Cultures } & 10\end{array}$

$\begin{array}{ll}\text { Cultural Influences on Health Care Services } & 17\end{array}$

$\begin{array}{ll}\text { Attitudes of Asians Toward Persons with Disabilities } & 18\end{array}$

Attitudes of Vietnamese Toward Persons with Disabilities 21

The Influence of Attitudes on the Psychosocial Adjustment 22

of Individuals with Physical Disabilities

Theories of Motivation $\quad 23$

Conceptual Frame of Reference in Occupational Therapy 24

Summary of Literature Review 29

CHAPTER THREE: DESIGN AND METHODOLOGY 31

$\begin{array}{ll}\text { Purpose } & 31\end{array}$

Research Questions 31 
TABLE OF CONTENTS -- CONTINUED

Sample Selection 32

Design and Instrument 32

Procedure 33

Data Analysis 34

CHAPTER FOUR: DATA AND RESULTS 36

Case Histories 37

CASE 1 -- Mai 43

CASE 2 -- Truc 46

CASE 3 - Huong 50

CASE 4 -- Thuy $\quad 56$

CASE 5 -- Minh $\quad 60$

CASE 6 -- Quan 65

Results and Discussion of Research Questions 69

$\begin{array}{ll}\text { Question one } & 70\end{array}$

Summary and Discussion of Question one $\quad 74$

Question two $\quad 75$

Summary and Discussion of Question two 79

Question three $\quad 82$

Summary and Discussion of Question three $\quad 86$

Question four $\quad 89$

Summary and Discussion of Question four $\quad 94$ 


\section{TABLE OF CONTENTS -- CONTINUED}

CHAPTER FIVE: DISCUSSION, PROFESSIONAL IMPLICATIONS 97 AND RECOMMENDATIONS

$\begin{array}{ll}\text { Introduction } & 97\end{array}$

$\begin{array}{ll}\text { Discussion } & 97\end{array}$

Implications for the Profession $\quad 104$

$\begin{array}{ll}\text { Recommendations } & 109\end{array}$

REFERENCES 112

APPENDIX A: Interview Questions 116

APPENDIX B: Consent Form (English) 120

APPENDIX C: Consent Form (Vietnamese) 122 


\section{LIST OF TABLES}

Table 1 Summary of the Participants' Background 38

Table 2 Participants' Chronological Age, Age Upon Immigration, and 40 Length of Time Living in the U.S.

Table 3 Information Regarding the Participants' Disabilities 


\section{CHAPTER 1}

\section{INTRODUCTION}

\section{Purpose}

This study explored the attitudes of Vietnamese people toward persons with physical disabilities as perceived by disabled Vietnamese individuals. The following attitudes were examined : (1) the attitudes of family members (i.e. parents, siblings, spouse) toward persons with disabilities, (2) the attitudes of non-family members (i.e. friends, co-workers, general public) toward persons with disabilities, and (3) the disabled persons' attitudes toward their disabilities and the disabilities of others. Furthermore, the study examined motivational factors that disabled individuals* utilized in psychosocial adjustment and self-improvement.

\section{Statement of the Problem}

A person's attitude toward one's own disability is affected by the attitudes of others toward physical disabilities (Pedretti, 1990). If others believe in a disabled person's abilities and challenge him/her to meet his/her potentials, he/she will be more likely to accept the disability and move toward a healthy adjustment. Negative attitudes toward persons with disabilities such as

*In this paper, children or adults with disabling conditions may also be referred to as physically handicapped, physically disabled, or disabled persons or children. It is clear that the disabling condition is only a secondary description of the person's physical status and is not intended to diminish the importance of the individual. The terminology is used only to simplify sentence structure. 
unworthiness and shamefulness may engender the feeling of nonacceptance in the disabled person. Undoubtedly, attitudes have an impact on the disabled person's self-perception and shape the process and outcome of rehabilitation (Versluys, 1983).

Culture plays a powerful part in shaping attitudes; it shapes the way people think, perceive, feel, and behave (Levine, 1987). MacGugan's work (1980) suggested the differences between Eastern and Western attitudes toward persons with disabilities, and Chan (1986) stated that "Traditional views of handicapping conditions and related coping strategies clearly influence the way Asian families respond to available services" (p. 45). With the notion that there are differences in cultural attitudes, and that attitudes greatly influence a person's participation and outcome in rehabilitation, therapists who work with Vietnamese clients must be aware of the assumptions and values that their clients and their families may have about physical disabilities. Increased awareness can help therapists become more culturally sensitive and better equipped to understand the underlying causes of a patient's motivation or non-motivation. With sensitivity and understanding, they can work toward eliminating the factors that hinder the patient's progress and foster the patient's acceptance of his/her disability.

Despite the importance of increased awareness regarding attitudes of Southeast Asians, who are a growing segment of the population in California (Congbalay, 1988), little published literature was found on their cultural values and beliefs, especially regarding handicapping conditions. No literature was found on the attitudes of Vietnamese toward persons with 
physical disabilities. The majority of the literature provides general descriptions of cultural health beliefs of Southeast Asians and the population's health issues.

\section{Research Questions}

The research questions generated for this study were:

1. As perceived by Vietnamese individuals who are physically disabled, what are the attitudes of family members toward them?

2. As perceived by Vietnamese individuals who are physically disabled, what are the attitudes of non-family members toward them?

3. What are the Vietnamese disabled individuals' attitudes toward their own disabilities and the disabilities of others?

4. What are the motivational factors that influence the Vietnamese disabled individuals in psychosocial adjustment and self-improvement?

\section{Definitions}

Terms associated with this study that may be considered ambiguous are defined by the researcher as follows:

1. Attitude: The way that people feel and think about issues as reported by respondents.

2. Culture: The customary beliefs, values, attitudes and social forms of an ethnic group. 
3. Family members: The members of the immediate family, which may include spouse, children, parents, siblings; and other members who are living in the household such as grandparents, aunts, uncles, and cousins.

4. Motivational factors: Factors, which may include personality traits, attitudes, environmental situations, social opportunities, that influence the person's motivation in his/her adjustment to his/her disability.

5. Non-family members: The subject's Vietnamese friends, co-workers, fellow students, and the Vietnamese in the general public. This group may also include relatives who are not part of the household.

6. Qccupational Therapy Services: The therapeutic use of self-care, work, and play activities designed to increase independent functioning, enhance development, and prevent disability. May include adaptation of task or environment to achieve maximum independence and to enhance the quality of life (American Occupational Therapy Association, 1986)

7. Perception: A person's interpretation of an event, attitude, or behavior.

8. Persons with Physical disabilities: Individuals who have lost a body part and/or body function which prevents them from performing a set of familial, occupational, and/or social roles. Please see Table 3 for specific information regarding the disabilities of the participants in this study.

9. Self-concept: A person's beliefs about his or her own image and abilities.

10. Self-help skills: Activities of daily living in the areas of dressing, toileting, and feeding (preparation of meals). 
11. Vietnamese: Individuals who were born in Vietnam and have been residing in the United States for at least 6 months.

Assumptions

The assumptions that viere made regarding this study are as follows:

1. The awareness of attitudes of Vietnamese people toward persons with physical disabilities will allow the occupational therapist to provide higher quality service to this population.

2. Cultural attitudes that are effective in the family and in the community may have a strong impact on the success of therapy.

3. The interviews used to collect data in this study were not threatening to the subjects.

4. Vietnamese individuals with physical disability live within Vietnamese families and interact with other Vietnamese people in the community.

5. Rapport between the interviewer and the subjects will permit open and honest answers to personal questions.

6. The Vietnamese interviewer is competent in her verbal and written skills in Vietnamese, and in her translation skill.

\section{Limitations}

Because this study was primarily concerned with discovering attitudes toward persons with disabilities, the in-depth interview method with a small 
sample size was appropriate. However, the small sample size prevents the results of this study from being generalized to the entire Vietnamese population. Furthermore, after collecting the data, the researcher realized that the backgrounds of the subjects were very broad. This limited the analysis for discovering themes that are common to all the subjects.

The fact that only the perceptions of disabled individuals were explored was another limitation of this study. This perception may not represent the actual attitudes of non-disabled Vietnamese people toward persons with disabilities. In addition, it was found that the subjects varied in the level of contact with Vietnamese people in the community and one subject did not have much contact at all. This posed a problem when trying to ask questions regarding their experiences interacting with the general Vietnamese population in the United States.

The study involved looking at personal issues regarding a person's disability. Culturally, Vietnamese individuals tend to have strong family bonds and prefer to keep personal and family affairs private (M. D. Nguyen, 1985). This made it difficult to enlist volunteers for the study or to elicit needed information from the participants. To alleviate part of this problem, the researcher used a third party who was trusted by the subject to make the initial contact. Also, the interviewer is Vietnamese and speaks the language so she was probably less threatening to the subjects and was eventually able to establish rapport with them. According to Oyster, Hanten, and Llorens (1987), the race of the interviewer has been shown to affect interview data and the effect is strongest on racially related topics. 
Lastly, the exact translation of the words the interviewees used to express their feelings and perceptions was difficult. In the researcher's attempt to ensure accuracy, she enlisted two native Vietnamese speakers to check the translations.

\section{Significance of the Study}

From 1975 to 1988 , approximately 861,700 refugees from Southeast Asia (Vietnam, Cambodia, and Laos) have moved to the United States (Congbabay, 1988). A 1990 Census indicated 614,547 Vietnamese people alone are living in the United States. Out of this total number, about 276,759 (45\%) have located in California (U.S. Bureau of Census, 1990 Census of Population and Housing, Summary Tape File $3 \mathrm{~A}$ and $1 \mathrm{C}$ ). This number is growing as more and more Southeast Asians are migrating to this state due to its wealth of opportunities, large Asian population, and warm weather.

The growing Southeast Asian population are potential consumers of occupational therapy services; therefore, therapists need to understand more about their culture to work effectively with them. The literature supports the value of heightened cultural awareness and sensitivity among professionals.

M. D. Nguyen (1985) stated that when two cultures coexist, misunderstandings will inevitably occur. He said, "The most sensitive situations require awareness of the basic values, beliefs, and traditions that have been imprinted [in the person] for an entire lifetime" (p. 412). In addition, cultural values have an impact on the provision of care to an individual (Felice, 1986; Levine, 1987; Ruddock, 1992). 
In treating an individual with physical dysfunction, psychosocial aspects are as important as physical components. The mind and the body are interrelated; therefore, to effectively guide the individual back toward health, both of these areas must be addressed (Burton, 1985; Pedretti, 1990). Attitudes have a powerful impact on a person's psychosocial adjustment, and culture plays an important role in shaping those attitudes (Levine, 1987). The successful therapist needs to be sensitive to the cultural values of the client and attempt to present therapy to the client in a way that is most acceptable (Burton, 1985). Versluys (1983) encourages therapists to become aware of certain cultural assumptions and values at the conscious as well as the unconscious level to avoid labeling patients as non-motivated.

Chan (1976) and Morrow (1987) identify punishment for wrong doing as a common explanation for disabling conditions used by some Asians. This belief creates barriers for understanding the disability and the disabled person's needs and potentials. With an understanding of the Vietnamese attitudes toward persons with physical disabilities, especially from the perception of the individuals with disabilities, a therapist can be better equipped to provide effective, quality care by addressing negative or positive unrealistic expectations. If acceptance and understanding of disability is modeled in the therapeutic environment, the client and his/her family may start to reformulate the role of the disabled and have more realistic expectations (Versluys, 1983), resulting in increased therapeutic effectiveness, participation, and acceptance. In addition, the understanding regarding disability will also enhance the rapport and trust needed between therapist and client. 
In addition to occupational therapy services, Southeast Asian refugees are also potential consumers of other health services (physical therapy, social services, psychiatry, medical, etc.) and special education services. Thus, the knowledge of attitudes of Vietnamese toward persons with disabilities can be valuable for working with Vietnamese patients in these other areas.

Lastly, the lack of research regarding Vietnamese attitudes toward physical disabilities supports the need for further study in this area. Few publications on the attitudes of Asians toward persons with disabilities were found. Only one study (unpublished thesis) was found that specifically looked at the perspectives of the Vietnamese regarding independence and role fulfillment of persons with disabilities (Stearns, 1988). 


\section{CHAPTER 2}

\section{LITERATURE REVIEW}

The literature review is presented first with an overview of Southeast Asian and Vietnamese cultures. The review then proceeds to present findings regarding attitudes of Asian and Vietnamese people toward disabilities, and the influence of attitudes on the psychosocial adjustment of persons with disabilities. Lastly, theories of motivation and the Model of Human Occupation are presented.

\section{Southeast Asian and Vietnamese Cultures}

Included under the label of Southeast Asian culture are several diverse and unique sub-groups. They are Vietnamese, Cambodian, Thai, and Laotian (Morrow \& McBride, 1988; West, 1983). Even though these sub-groups share some similar cultural values, each has its own history, customs, and beliefs. Due to this ethnic variation within the Southeast Asian group, one must be cautioned not to make inappropriate generalizations about their cultures (Cohon, 1983; Felice, 1986). Other variances beside ethnic variation are levels

of education and social class. The "first wave" of Southeast Asian refugees in 1975 were generally well educated, familiar with Western ways, and from high socioeconomic classes. The "second wave" of refugees arriving in 1979 and after included a higher number of people who had little or no formal education and lived in rural areas (Felice, 1986; Muecke, 1983; West, 1983). 
Furthermore, the diversity of the Southeast Asian population reflects not only cultural and subcultural differences, but also the individual personality characteristics of members in each subgroup.

The following are general descriptions of common cultural characteristics among the Vietnamese people.

The Family Unit

M. D. Nguyen (1985) defines family in traditional Vietnamese society as the fundamental social unit, the primary source of cohesion and continuity. A Vietnamese family is usually extended, consisting of several generations, including the nuclear family, the grandparents, some siblings and their families.

Roles within a family emphasize subordination. The man is generally the head of the household who takes care of all business outside of the home and supports the family financially. The wife is in charge of taking care of the household and educating the children. Children are considered to indicate prosperity and therefore a large family is desirable. As children mature and have younger siblings, they too must take on the responsibility of child rearing as indicated by their parents. Younger siblings are expected to respect the older siblings. The parents' concerns revolve around their roles as parents and their responsibilities for childrearing. In turn, parents demand respect and obedience from their children (Chan, 1986; Dung, 1984).

In the traditional Vietnamese family, a great deal of emphasis is placed on filial piety--a crux of family loyalty which requires the children to respect the parents' wishes and values. The children are taught to think of the family first and must learn to subjugate their personal desires and concerns (Morrow 
\& McBride, 1988). Relationships in the family emphasize interdependence. Each individual views himself as an integral part of the totality of the family. Behavior of a family member will reflect on the whole family. On one hand, highly-valued individual academic achievements promote the family pride, but, on the other hand, negatively-valued behavior such as being disrespectful or shirking responsibilities results in collective family shame (Morrow \& McBride, 1988; M. D. Nguyen, 1985; Vuong, 1987).

The first loyalty of Vietnamese people is to the family. Instead of seeking outside persons or agencies for assistance, Vietnamese people rely on their families for economic, social, and emotional support.

\section{Religious beliefs}

The Vietnamese are strongly influenced by Cult of the Ancestors, Buddhism, Confucianism, and Taoism (Dung, 1984; D. L. Nguyen, 1985; M. D. Nguyen, 1985). M. D. Nguyen (1985) also mentions Catholicism, which was more recently introduced to Vietnam, as other influencing sets of religious beliefs.

\section{Cult of the Ancestors}

Ancestors are believed to be the natural protectors of the family's life. In the family, the ancestors' altar is the piece of furniture of greatest value. It is before the altar that major decisions are made and marriages consumated.

The fear of offending the ancestors coupled with the desire to please them are sources of inspiration, which guide the actions of the people. Lack of respect for the ancestors is the worst offense imaginable (D. L. Nguyen, 1985). 


\section{Buddhism}

Buddhism is based on the concept that suffering is caused by too much desire: desire for life's material things, pleasures, riches, or power. With corrective behavior, desire can be eliminated and suffering in life lessened (M. D. Nguyen, 1985). The essence of Buddhist teaching is contained in the concept of Karma, "the present existence is conditioned by earlier existences and will condition those that follow" (D. L. Nguyen, 1985, p. 38). Thus, a person should strive to improve by doing good deeds and renouncing pleasures. Buddhists believe silence is a virtue, and advocate self-negation, self-sacrifice, modesty, humility, perseverance and unconditional kindness toward others (Dung, 1984).

\section{Confucianism}

Confucianism is more a way of life than a religion. Confucian teaching points are: the innate goodness of man, self-perfection, and social relations (M. D. Nguyen, 1985). Man is inherently good. If men do not live up to their potential goodness, it is because they have neglected their intellect. A wise man improves through his study and is in control of his passions. For this, he will be honored and and his soul will be at peace.

According to Confucius, the four rules to self-perfection are: interest in everything that exists, ability to penetrate the secret of things, clear thinking, and a pure heart.

There are clear rules of social hierachy in Confucianism. These rules define the attitudes that each member of the society should have. They prescribe the formula for three sets of social interaction: between ruler and 
subject, between father and son, and between husband and wife. It also dictates the moral code of humanity, equity, intelligence and honesty.

Confucianism also involves ethical codes of: respect for the elderly, value of education, and loyalty to family. Worship of ancestors is stressed (Dung, 1984).

\section{Taoism}

Taoism advocates blending with nature and establishing harmony with self, with fellow human beings, and with the universe. Perfection and harmony can be achieved by permitting things to take their natural course. Confrontations should be avoided and problems should be approached indirectly. Charity, simplicity, and patience are valued characteristics (Dung, 1984; D. L. Nguyen, 1985).

\section{Catholicism}

Catholicism is based on the belief and commitment to the reality of God. The church gives people access to Jesus Christ and Jesus Christ gives access to God. Catholics adhere to the belief of one God who made the heavens and the earth, and all things visible and invisible. Catholics believe that humans came forth from the hand of God as essentially good and that sin is part of the human condition. However, the belief also holds that human kind is redeemable because men and women are good. Their sins can be obliterated by an act of divine forgiveness and generosity, on the sole condition that they are truly sorry for their wrong doings (Eliade, 1987).

Dung (1984) stated that religions in Vietnam are not mutually exclusive. A Vietnamese family may select its own beliefs from among the various religions. 
Value System

Education is highly valued in Vietnamese culture (Dung, 1984; Vuong, 1987). The children are taught at an early age to respect teachers and to study hard. Traditionally, educated people have held an honored place within the society.

Teaching children appropriate manners is very important to the Vietnamese. At an early age, children are taught by their parents to control their emotions and to respect elders (Dung, 1984). Questioning a higher authority (teachers, parents, doctors, and elders) is considered to be impolite and "uneducated." Status is more important than wealth; therefore it is important to address a Vietnamese person by his title. For example, "Teacher so and so" or "Lawyer so and so."

Strong bonds between family members are emphasized. The focus is to maintain the family as a strong unit under all circumstances, and to enhance the family name. Personal matters that embarrass, cause hurt or stress are not usually discussed with anyone except with family members and close friends (Morrow \& McBride, 1988; Vuong, 1987).

In Southeast Asian culture, "saving face" is a crucial element. "Losing face" produces great embarrassment (Felice, 1986; West, 1983). For example, a worker "loses face" when his/her colleague directly corrects his/her mistake, especially in the presence of others. However, the worker is able to "save face" when his colleague indirectly brings the mistake to his attention so that he can appropriately correct it.

Self-control is a traditional value to the Vietnamese. People keep feelings to themselves and avoid disagreements, especially with persons who are 
considered superior such as teachers, physicians, and parents. There are deep cultural restraints against showing "weakness" of the mind. Emotions are weaknesses because they interfere with self-control. Persons should not be swayed by emotions or permit others to see that they are troubled by intimate feelings. "Denial and avoidance" is a step of self-control where people try to forget the sorrow and hope for the best. They use "destiny" as a form of rationalization (M. D. Nguyen, 1985).

Both Confucian and Buddhist concepts and beliefs have been transmitted through the generations to produce an attitude toward life that may be perceived as passive. These concepts encourage personal reserve and modesty. Vietnamese persons possess an inwardness, a well-developed ability to keep their true feelings hidden. Desires are expressed by indirection and hinting. For example, the answer "Yes" may reflect either an avoidance of confrontation or a desire to please rather than an affirmation of truth (M. D. Nguyen, 1985).

\section{Health Beliefs}

The Vietnamese health system consists of a combination of various influences including indigenous practices, Chinese practices, and Western practices (Cohon, 1983). Indigenous beliefs consist of knowledge about herbs, special diets, or simple medical measures based on experience. This knowledge is usually passed down orally within families. An example is the "coin rubbing" treatment for the common cold, flu, or headache. Rubbing a coin across the skin makes the skin red and supposedly permits the sickness to escape. 
Chinese medicine is centered in the belief of achieving a balance between Yin and Yang. One of the most basic belief is that food should be balanced between "hot" and "cold" in order to maintain harmony and good health. Acupuncture and herbal remedies are also used.

Western medicine was introduced to Vietnam by European missionaries and subsequently augmented by the French. Although traditional medical beliefs still are an important part of the Vietnamese health system, the people have greater acceptance of the Western techniques after witnessing its effectiveness.

\section{Cultural Influences on Health Care Services}

Cultural attitudes and values influence the process and the outcome of any therapeutic intervention. Culture effects how patients view their health, their acceptance of health care, and their respect and trust of the health care providers (Versluys, 1983; Burton, 1985). Ruddock (1992) identifies the Asian cultural value of interdependence as having an affect on occupational therapy goals. The therapist may need to involve the whole family in the treatment process. In addition, the therapist may also need to change a commonly-held American goal in therapy: independence. If it is the family's responsibility to care for the person and there is no value placed on independence, then enabling the person to function more independently is not a goal issue.

The power of the Vietnamese family also influences health care. The entire family is usually involved in making health care decisions for a family member (Felice, 1986; M. D. Nguyen, 1985). In addition, the custom of not 
revealing problems to those outside the family may prevent a person from seeking counseling or psychotherapy services (West, 1983). Sharing problems with those outside of the family is considered to be a sign of weakness.

Cultural values also influence the interaction style and the development of trust between clients and health care professionals. Asians generally expect health professionals to be experts in diagnosis and treatment. Health care professionals are considered to be authority figures who are directive, and provide specific answers and recommendations. It is believed that health professionals should not be questioned or opposed directly (Chan, 1986; Muecke, 1983).

Attitudes of Asians Toward Persons with Disabilities

An extensive search revealed only limited literature addressing the attitudes of Asians toward persons with physical disabilities (Chan, 1976; Chan, 1986; Gee, 1987; MacGugan, 1980; Morrow, 1987).

Chan (1976) described handicapped Asian Americans as "a minority group within the handicapped minority group" (p. 14). Many Asian Americans view the disabled individual as "an unsound and incomplete person who has been cursed for a sin committed by his/her ancestors and/or himself" (Chan, 1976, p. 14). Thus, the disability brings embarrassment to the individual and the family forcing them to cope with the impact of the disability on the family's "good name." Knowing that no one is immune from such "punishment," the general public often stays silent and ignores the individual. They attempt to distance themselves from the fear that this 
punishment could happen to them also. Barriers are then further created to prevent understanding about disability.

There is a lack of interest in remedial therapy because the disability is believed to result from wrongdoing. The disabled individual may be reinforced to believe this perception and decide to accept the punishment and not be motivated for rehabilitation. The notion of hereditary taint coupled with the Asian pride in providing for their own family members, as well as the need to keep the family affairs private, contributes to the problem of neglecting to educate or to seek help for the disabled child or adult (Chan, 1986). Furthermore, Asian people feel obligated to help any member of the family in time of need; therefore, in order for the members to save the family from disgrace, they must take care of the less able members (Chan, 1976).

Another belief is that a child's disability results from the thoughtless acts of the mother during pregnancy. This brings much guilt to the parents. For example, a mother of a child with a cleft palate believed that the disability was related to her seeing horror movies during her pregnancy. Some people believe that the handicapped individual is possessed by demons, ghosts, or evil spirits. Thus, the family of the individual may seek the help of religious persons to drive the "demon" from the person's body (Chan, 1986; Morrow, 1987).

Apart from moralistic, superstitious, and spiritual attributions, another belief held by Asians to explain handicapping conditions is an imbalance of the forces Yin and Yang. Good health is achieved only when these two forces are balanced. Some Asian families may relate the imbalanced condition to an unbalanced diet during the mother's pregnancy. For example, a parent may 
believe that hypotonia in a Down Syndrome child was caused by the failure to drink enough beef bone soup during pregnancy (Chan, 1986).

Only two studies were found that focused on the attitudes of Asian people regarding persons with disabilities. A 1987 unpublished study "Attitudes of Bay Area Chinese-Americans toward the stroke-impaired" (Gee, 1987), and a 1980 study "East/West attitudes toward the handicapped and their presence in Postsecondary Education in Hawaii" (McGugan, 1980).

Gee (1987) examined the attitudes held by Cantonese and/or Toishanese speaking Chinese-Americans in the San Franciso Bay Area toward the strokeimpaired. Attitudes regarding the stroke-impaired in the following areas were examined: self-care, work, leisure interests, personality traits, and capabilities. She found a wide variety of attitudes. She concluded that the subjects' age, length of stay in the United States, and level of education influenced their attitudes toward the stroke-impaired. Subjects who are younger, subjects who have been in the United States for relatively shorter time, and subjects with higher educational level generally have more positive attitudes toward the stroke-impaired.

MacGugan (1980) investigated the cultural differences in attitudes toward the handicapped and their presence in postsecondary institutions in Hawaii among faculty with Eastern and Western cultural backgrounds. She presented results indicating that Easterners and Westerners perceive, and treat disabled persons differently.

Some of the differences in attitudes found between Westerners and Easterners were: (1) Westerners perceive a disabling condition as an external challenge; Easterners perceive a disabling condition as an internal 
punishment. (2) Westerners tend to isolate the disabled person within institutional settings; Easterners tend to isolate the disabled person within the family. (3) Westerners feel a social responsibility owed to the disabled person; Easterners feel that the disabled person is the family's responsibility. And (4) Westerners hold the value that one must work to be a worthy citizen; Easterners want to keep the disabled person from public view.

\section{Attitudes of Vietnamese Toward Persons with Disabilities}

A review of the literature revealed no studies that explored the attitudes of Vietnamese toward the physically disabled. However, in review of the Southeast Asian cultures and beliefs, many similarities are evidenced between the cultures. This suggests the possibility that Vietnamese people may share attitudes with the general Asian population toward the physically handicapped.

One study (Stearns, 1988) examined the Vietnamese perspectives on independence of the disabled in their home and community environments, and role fulfillment of the disabled. Some of the findings of this study are: (1) Vietnamese who have disabilities may want independence in certain daily activities but they also may feel obligated to accept assistance from a family member. (2) The valued role for younger and older men is teacher, for younger and older women is child-care provider, and for boys and girls is that of student. (3) If assistance is required, the Vietnamese appear to prefer that a female in the family be the caretaker. And (4) Vietnamese are reluctant to use 
community-based programs, preferring instead to provide for family members within the family system.

The Influence of Attitudes on the Psychosocial Adjustment of Individuals with Physical Disabilities

The perception of disability, the acceptance of the disabled person, and the intensity of feelings toward a specific handicap are strongly influenced by the individual's cultural background (Burton, 1985; Versluys, 1983). Pedretti (1990) states that "attitudes of others toward physical disability affect attitudes toward oneself" (p. 12). Some of the misconceptions about the physically disabled persons are that they are "retarded, not employable, dependent, helpless, asexual, unlovable, and miserable" (Burton, 1985, p. 120). These negative role expectations may be fulfilled by the disabled individuals if they are reinforced by society and family.

Harvey and Greenway (1982) studied the effect of parents' attitudes on the handicapped child's self-concept with a sample of 24 parent-child pairs. The parents' responses to a Primary Mood Factors grid were compared with their children's responses on a Self-concept scale. The results indicate that parents who were the "fighters" had children who scored higher on the Self-concept scale. Parents who felt constrained by the handicap had children who scored lower on the Self-concept scale.

Another study conducted by Beail (1983) compared how physically disabled adults see themselves with what they think is the stereotype of society. Fourteen males and 16 females were surveyed. The results demonstrated that 
the subjects reject the stereotype of the disabled; however, the stereotype has a powerful influence in that it gives a defined frame within which the disabled can be viewed.

\section{Theories of Motivation}

Maslow (1970) proposed a hierarchy of basic needs. Presented in order of lower to higher, these needs are: physiological needs, safety needs, belonging and love needs, esteem needs, and the need for self-actualization. When lower needs are satisfied, new and still higher needs emerged. For example, if all needs are unsatisfied, the person will then be dominated by the physiological needs and unable to actualize to satisfy higher level needs. On the other hand, if the prior physiological, safety, love, and esteem needs are satisfied, a person may develop desires to become actualized in his/her potential. Maslow (1970) indicated that most people seemed to have the above basic needs in about the order that has been indicated. However, there have been some exceptions. For example, innately creative people in whom the the drive to create (self-actualization) is present in spite of a lack in basic need satisfaction (physiological, safety, love, and esteem).

Deci and Ryan (1985) stated that humans have needs for competence and self-determination. The need for competence leads people to seek and conquer challenges that are optimal for their capacities, and competence acquisition results from interacting with stimuli that are challenging. The need for self-determination is the need to have a choice of whether to be in control. These intrinsic needs motivate an ongoing interaction with the 
environment of seeking and conquering challenges that are optimal for one's capacities. The emotions of enjoyment and excitement accompanying the experiences of competence and autonomy represent the rewards for intrinsically motivated behavior.

Conceptual Frame of Reference in Occupational Therapy

The Human Occupation Model was used to guide this research. Of central importance to this model is that human beings are open systems, and that they have intense commerce with their environment through cycles of intake, throughput, output and feedback (Kielhofner \& Burke, 1986).

\section{The Open System}

The input phase represents the absorption of energy and information from the environment. The environment consists of the physical, social, and cultural setting in which the human operates, such as external objects, people, and events. The throughput phase is the internal organization process which transforms the information into some useable form and integrates it into the system. The output phase comprises the mental, physical and social aspects of occupation; it is what the human produces. When a human receives information about the process or consequences of his/her actions, this in turn becomes part of the input of the human open system, thus making up the feedback phase. 


\section{Occupational Behavior and Its Motivation}

Occupational behavior is the output of the system and is defined by Kielhofner and Burke (1986) as:

An activity in which persons engage during most of their waking time; it includes activities that are playful, restful, serious and productive. These work, play and daily living activities are carried out by individuals in their own unique ways based on their beliefs and preferences, the kinds of experiences they have had, their environments and the specific patterns of behaviors that they acquire over time (p. 12).

To explain how occupational behavior is motivated, organized and performed, the human occupation model was created to conceptualize the human system as composed of a hierarchy of three subsystems. At the top of the hierarchy is the volition subsystem which guides the choices of occupational behavior through personal causation, valued goals and interest. Habituation is the middle subsystem which organizes occupational behavior into patterns or routines. The lowest subsystem is human occupation which is responsible for producing occupational behavior (Kielhofner \& Burke, 1986). These three subsystems work together to allow the human being to ouput occupational behavior.

The volition subsystem is conceptulalized to address how occupational behavior is motivated. The humans' need to explore and master themselves and their world is the energizing component that determines conscious choices. Volition is thought to be composed of symbols that a person holds 
about exploring and mastering his/her world. These symbols consist of values, personal causation, and interests. Personal causation, the beliefs and expectations that a person holds about his/her effectiveness in the environment, influences the degree of challenge that one is willing to seek. Values and interests determine the types of settings that will attract a person. That is, the individual is energized by the urge to explore and master, but the urge is influenced by what the person perceives to be interesting and valuable, and by what the person believes himself/herself capable of doing. Symbols of the volitional subsystem are continuously generated and modified through experience as the person interacts with the environment (Keilhofner \& Burke, 1985).

\section{Occupational Function and Dysfunction}

The Model of Human Occupation stresses the importance of function and adaptation as criteria of health. The open system (a person) can continue to function in spite of damage to its parts (a bodily part or function) through adaptation. There are three levels of occupational function. They are exploration, competence, and achievement. Achievement is the highest level signified by the development of sufficient skills and habits to allow control over his/her own performance and other factors in the environment. The level of achievement depends on the person's belief in his/her internal control and personal skills. Inefficacy, incompetence, and helplessness are the three levels of occupational dysfunction. It is a disruption of the open system (the human) which causes a decrease, cessation or imbalance of output (occupational behavior) and subsequently disorganization of the internal subsystems and their components (volition, personal causation, and values). 
Physical disabilities are disturbances to the human open sytem. They disrupt and place new demands on the habits and roles which regulate patterns of routine behavior. This disruption confronts the person with experiences that challenge and contradict a view of self as competent. The person is then required to adjust his/her values and goals. Volitional elements are critical determinants of the physically disabled person's maintenance of, or return to, occupational functioning. Environment is believed to be one of the most critical variables affecting occupational behavior of the persons with disabilities. The environmental levels consist of objects, tasks, social groups, and culture (Kielhofner \& Burke, 1985). The Role of Occupational Therapy

Occupational therapists assist in the reorganization of all the subsystems in the human open system by engaging the disabled person in occupations and by modifying the environment to facilitate function. The process of therapy is one of providing opportunities for occupational function until the person can maintain an adaptive open system cycle of his/her own. Whereas occupational therapists do not treat the whole person, they should treat the person holistically. This means that an occupational therapist must take into consideration the person's external environment as well as the person's internal values, interests, and needs in setting up therapeutic environments. Human Occupation Model and Research Questions

The Human Occupation Model stresses the role of environment in shaping occupational behavior, and occupational behavior is guided by the human's volitional subsystem. It follows that in occupational therapy treatment, it is crucial for therapists to understand the environment that 
patients bring with them to therapy and the motivational factors that guide their actions. With this information, the therapist can then set up appropriate therapeutic environments that facilitate adaptation and foster functional behavior.

Keilhofner and Burke (1985) identify culture as an environmental level. Culture strongly influences how people perceive activities and it determines what goals people value. Cultural beliefs also affect people's attitudes regarding health and disabilities; therefore, they affect their perceptions of the worth of their abilities. Thus, in attempting to understand the patients' environments, the therapist will need to explore the patients' cultural values, beliefs, and attitudes as well as other physical aspects of their environments.

The goal of occupational therapy is to influence the patient (the human open system) through providing appropriate therapeutic settings for exploration. The therapist attempts to elicit performances (occupational behaviors) by incorporating factors that motivate the patients. Successful performances (competent occupational behavior) then provide feedback to the patients and help modify and reorganize their values, interests, and beliefs about their effectiveness in the environment. Over time, new roles and habits are adapted and occupational function is achieved.

This study is an initial exploration of an important part of the participants' environment--their cultural beliefs and attitudes regarding disabilities. The study also attempts to understand the motivational factors that guide the participants' urge to explore and master. With knowledge of the above information, the therapist can then set up meaningful therapeutic activities 
and successfully motivate the patients to produce competent occupational behaviors. The therapist is then able to guide the patients toward adaptation and function.

\section{Summary of Literature Review}

Many of the cultural beliefs, values, and health care practices of Southeast Asians differ from those of the majority of Americans. These cultural characteristics shape the way a person interacts with health care professionals, accepts health care services, views disabling conditions, and defines the goals of rehabilitation.

The literature supports the idea that culture is an influencing factor on attitudes, a contribution to a person's perception of disability and acceptance of the disabled person (Burton, 1985; Levine, 1987; Livneh, 1982; Pedretti, 1990; Versluys, 1983). Attitudes of others toward disabilities may influence a person's self-concept, and therefore influence the motivation and outcome of rehabilitation.

Cultural attitudes of Vietnamese toward physical disabilities probably will have a powerful impact on the psychosocial adjustment of Vietnamese disabled individuals in the United States. Furthermore, these attitudes are important in the development of a Vietnamese disabled child, whether that attitude is negative or positive. Nevertheless, there have been limited studies found regarding attitudes of the general Asian population, and none specifically to the Vietnamese, toward persons with disabilities. 
Theories of motivation propose that humans have needs to master the environment (Deci \& Ryan, 1985; Kielhofner \& Burke, 1985). There is also a hierarchy of needs where higher needs emerge when lower needs are satisfied (Maslow, 1970). According to the Model of Human Occupation, the human being is an open system who interacts with the environment by the process of input, throughput, output and feedback. Physical disabilities disrupt the system and requires adaptation. Occupational therapy provides an environment for the person with disability to learn or relearn new skills and reorganize the open system for function (Kielhofner \& Burke, 1985). 


\section{CHAPTER 3}

\section{DESIGN AND METHODOLOGY}

\section{Purpose}

This study explored the attitudes of Vietnamese people toward persons with physical disabilities as perceived by disabled Vietnamese individuals. The following attitudes are examined : (1) the attitudes of family members (i.e. parents, siblings, spouse) toward persons with disabilities, (2) the attitudes of non-family members (i.e. friends, co-workers, general public) toward persons with disabilities, and (3) the disabled persons' attitudes toward their own disabilities and the disabilities of others. Furthermore, this study examined motivational factors the disabled individuals utilized in psychosocial adjustment and self-improvement.

\section{Research Questions}

The research questions generated for this study were: 1. As perceived by Vietnamese individuals who are physically disabled, what are the attitudes of family members toward them?

2. As perceived by Vietnamese individuals who are physcially disabled, what are the attitudes of non-family members toward them?

3. What are the Vietnamese disabled individuals' attitudes toward their own disabilities and the disabilities of others? 
4. What are the motivational factors that influence the Vietnamese disabled individuals in psychosocial adjustments and self-improvement?

\section{Sample Selection}

The criteria for subject participation in this study were as follows:

1. Vietnamese persons who were born in Vietnam and presently reside in the United States for at least 6 months.

2. Vietnamese persons with a physical disability, either congenital or with an onset of at least 6 months prior to the interview.

3. Vietnamese persons who were cognitively intact and have means to communicate clearly.

Subjects were sought through community organizations, religious organizations, family members, and friends.

\section{Design and Instrument}

This research was designed as an exploratory study utilizing qualitative case study methodology. It is a preliminary study which uses an in-depth interview method. Because the study aimed to gain complex information about attitudes toward Vietnamese individuals who have a physical disability, interview questions were open ended to allow the respondents to identify the areas of their concern instead of forcing them to choose among predefined response categories. 
The researcher developed an interview guideline that consisted of questions directed toward obtaining information in the areas of (1) demographics, (2) self-concept and motivation to achieve goals, (3) personal experiences and perception regarding the family's attitudes toward the person's disability, and (4) personal experiences and perceptions regarding non-family members attitudes toward the person's disability (see Appendix A). During the interview, the interviewer had the freedom to rephrase or clarify the questions as needed. Additional questions were also used to gain more in-depth information and/or to further explore an emerging issue of concern. Consistency among the interview questions was maintained, however, to allow the researcher to analyze the data and identify emergent themes.

\section{Procedure}

Vietnamese people sometimes distrust strangers and prefer not to discuss their personal affairs with them. Therefore, in order to increase agreement to participate, individuals who met the established criteria were initially contacted by third party persons. Third party persons used in this study included religious leaders, family members, relatives, friends, and co-workers who are trusted by the individuals with disability. The researcher secured these contact people mainly by word-of-mouth through her family and friends.

Once the researcher was informed by a contact person that an individual agreed to participate in the study, the researcher then called him/her to 
explain the research goals, general procedures, and participants' rights. If the individual continued to agree to participate, an interview date, time, and location that were convenient for the individual were scheduled.

Data were gathered by means of in-depth interviews, using the interview outline developed by the researcher (Appendix A). As issues emerged, the interviewer would make a note on the questionnaire to further investigate. Also, the interviewer summarized key concepts to check back with the subject for accuracy. Each interview was completed in one session and lasted from one to two hours. Participants who are bilingual were permitted to chose the language (Vietnamese or English) in which they would be interviewed.

At the beginning of each meeting, the interview process was explained and the participants' signatures were obtained on the consent forms (Appendices B \& C). The consent form to participate in the study was translated from English to Vietnamese by a native Vietnamese speaker then back translated by another native Vietnamese speaker to ensure accuracy. The participants could choose the language of the consent form that they preferred to use. With the participants' prior knowledge and permission, the interviews were audio tape-recorded for accuracy of data collection.

\section{Data Analysis}

Data were analyzed using qualitative methods as described by Taylor and Bogdan (1984) and Patton (1987). Each of the recorded interviews was transcribed verbatim, each as its own case study. As the researcher read through each case, key words and phrases were highlighted, and key concepts 
were noted in the page margins. These key words and concepts were then transferred onto a grid of pre-defined topic headings. They included (1) the perception of family's attitudes, (2) the perception of non-family's attitudes, (3) disabled persons' attitude toward disabilities and (4) major influencing factors for motivation and adaptation. Next the grid was reviewed to identify any recurring concepts or themes throughout the six interviews. These themes were then used to answer the research questions. 


\section{CHAPTER 4}

\section{DATA AND RESULTS}

Data were collected over a six month period from April 1994 through September 1994 from six subjects who ranged in age from 25 to 53 . The location of the interview sessions were decided by the participants according to convenience and comfort of the participants. Four of the interviews were conducted at the homes of the participants. One interview was conducted at the contact person's home, and one at a temple where the participant attends regularly. Five of the interviews were conducted in Vietnamese and one was conducted in English.

\section{Subjects}

Subjects for the study were six adults (four females and two males) who met the established criteria. Of the six participants, four are single and two are married. Two are monolingual in Vietnamese, three are bilingual in Vietnamese and English, and one is fluent in English and understands limited Vietnamese. Duration of stay in the United States, level of education, and religious beliefs vary among the participants. Three of the participants' disabling conditions resulted from contracting poliomyelitis in early childhood years while living in Vietnam. One also became disabled during her childhood years but the cause is unknown. The other two participants became disabled later in their lives, one from a stroke in Vietnam and one as 
a result of the Vietnam war. All six participants are ambulating independently by walking, using crutches, or using a wheelchair. The characteristics of the participants are summarized in Tables 1, 2, and 3.

The subjects were introduced to the researcher through family, friends, and a religious organization (Hayward Vietnamese Buddhist Temple). The first six persons who agreed to participate in the interviews were selected.

\section{Case Histories}

Case history data are presented descriptively in the order of the participants' age, from the youngest to the oldest. The cases provide a summary of the subjects' history and experiences that were obtained in the interview process. Each of the summaries has four sections: (1) Background, (2) Experiences with Family Members, (3) Experiences with Non-Family Members, (4) Personal Beliefs and Motivation. Due to the requirement for confidentiality, each participant has been given an assumed name. 


\section{Table 1}

Summary of the Participants' Background

\begin{tabular}{|l|l|l|l|l|}
\hline Participants & Gender & Education & Religion & $\begin{array}{l}\text { Region } \\
\text { Lived in } \\
\text { Vietnam }\end{array}$ \\
\hline Mai & female & $\begin{array}{l}\text { college; presently } \\
\text { attending School } \\
\text { of Optometry }\end{array}$ & Buddhist & urban \\
\hline Truc & female & $\begin{array}{l}\text { never had formal } \\
\text { education; does } \\
\text { know how to read } \\
\text { and write }\end{array}$ & Buddhist & $\begin{array}{l}\text { rural/ } \\
\text { urban }\end{array}$ \\
\hline Huong & female & $\begin{array}{l}\text { no formal } \\
\text { schooling in } \\
\text { Vietnam; began } \\
\text { schooling in U.S; } \\
\text { presently studying } \\
\text { business }\end{array}$ & Buddhist & $\begin{array}{l}\text { rural/ } \\
\text { urban }\end{array}$ \\
\hline
\end{tabular}

Continued ... 
Table 1 (Continued)

Summary of the Participants' Background

\begin{tabular}{|l|l|l|l|l|}
\hline Participants & Gender & Education & Religion & $\begin{array}{l}\text { Region } \\
\text { Lived in } \\
\text { Vietnam }\end{array}$ \\
\hline Thuy & female & $\begin{array}{l}\text { college; presently } \\
\text { attending medical } \\
\text { school }\end{array}$ & Catholic & urban \\
\hline Minh & male & $\begin{array}{l}\text { attended college in } \\
\text { Vietnam }\end{array}$ & Buddhist & rural \\
\hline Quan & male & $\begin{array}{l}\text { attended up to } \\
\text { elementary level } \\
\text { in Vietnam }\end{array}$ & Catholic & urban \\
\hline
\end{tabular}


Table 2

Participants' Chronological Age. Age Upon Immigration, and Length of Time Living in the U.S.

\begin{tabular}{|l|c|c|c|}
\hline Participants & $\begin{array}{l}\text { Chronological } \\
\text { Age (y.o.) }\end{array}$ & $\begin{array}{l}\text { Age when } \\
\text { Immigrated to } \\
\text { the U.S. (y.o.) }\end{array}$ & $\begin{array}{l}\text { Years Lived in } \\
\text { the U.S. }\end{array}$ \\
\hline Mai & 24 & 7 & 17 \\
\hline Truc & 27 & 24 & 3 \\
\hline Huong & 32 & 18 & 14 \\
\hline Thuy & 34 & 18 & 16 \\
\hline Minh & 47 & 46 & 1 \\
\hline Quan & 54 & 43 & 11 \\
\hline
\end{tabular}


Table 3

Information Regarding the Participants' Disabilities

\begin{tabular}{|l|c|l|l|}
\hline Participants & $\begin{array}{l}\text { Age of Onset } \\
\text { of Disability } \\
\text { (y.o.) }\end{array}$ & Nature of Disability & Functional Abilities \\
\hline Mai & 2 & poliomyelitis & $\begin{array}{l}\text { ambulates using } \\
\text { braces and crutches; } \\
\text { drives a car; } \\
\text { participates in sports; } \\
\text { independent in all } \\
\text { self-help skills }\end{array}$ \\
\hline Truc & 5 & $\begin{array}{l}\text { lost function of her } \\
\text { legs due to an } \\
\text { unknown cause }\end{array}$ & $\begin{array}{l}\text { ambulates by using } \\
\text { crutches or a walker; } \\
\text { participates in } \\
\text { physical therapy; } \\
\text { independent in all } \\
\text { self-help skills }\end{array}$ \\
\hline Huong & 3 & poliomyelitis & $\begin{array}{l}\text { ambulates by using } \\
\text { braces, crutches, or } \\
\text { wheelchair; drives a } \\
\text { car; participates in } \\
\text { sports; independent } \\
\text { in all self-help skills }\end{array}$ \\
\hline
\end{tabular}

Continued ... 
Table 3 (Continued)

Information Regarding the Participants' Disabilities

\begin{tabular}{|l|c|l|l|}
\hline Participants & $\begin{array}{l}\text { Age of Onset } \\
\text { of Disability } \\
(\text { y.o })\end{array}$ & Nature of Disability & Functional Abilities \\
\hline Thuy & 1 & poliomyelitis & $\begin{array}{l}\text { ambulates by using } \\
\text { braces and crutches; } \\
\text { drives a car; } \\
\text { independent in all } \\
\text { self-help skills }\end{array}$ \\
\hline Minh & 26 & $\begin{array}{l}\text { above knee } \\
\text { amputation } \\
\text { resulting from the } \\
\text { Vietnam war }\end{array}$ & $\begin{array}{l}\text { ambulates by using a } \\
\text { wheelchair; can } \\
\text { move about the floor } \\
\text { independently } \\
\text { propelling with his } \\
\text { arms; independent } \\
\text { in all self-help skills }\end{array}$ \\
\hline Quan & 30 & $\begin{array}{l}\text { right hemiparesis } \\
\text { resulting from a } \\
\text { stroke }\end{array}$ & $\begin{array}{l}\text { walks without } \\
\text { assistive devices; } \\
\text { drives a car; } \\
\text { independent in all } \\
\text { self-help skills }\end{array}$ \\
\hline
\end{tabular}




\section{CASE 1 - Mai}

\section{Background}

Mai is a 24 year old single woman who immigrated with her family to the United States when she was 7 years old (in 1975). She has been enrolled in the U.S. educational system since that time. She is presently in her second year of Optometry school.

Mai contracted poliomyelitis when she was 2 years old. She has used braces and crutches since 5 years of age. Mai can drive a car and is independent in her daily self-help skills. She enjoys physical activities such as skiing, canoeing, and "working out" at the gym. Mai understands limited Vietnamese but has difficulty speaking it. She is fluent in English.

\section{Experiences with Family Members}

Mai has two brothers; one older and one younger. Her father is a doctor and her mother was a nurse. She lived with her parents until about a year ago when she entered optometry school. She is now living in an apartment with a roomate and returns to her parents' home as often as possible.

Mai described her parents as "very protective" of her, much more with her than of her siblings. She went on to say that often her parents' protectiveness had an "opposite effect" on her. She described herself as "stubborn," and explained that she would try even harder to do things by herself or to pursue her interests if she was told "no." Nevertheless, she expressed that sometimes when she feels tired of trying, it is nice to feel that her parents are there to protect and to help her. Mai said that her brothers treat her "normal" and that they "keep her on her toes." 
Mai feels that her parents' attitudes towards her disability have changed through the years as she was able to show them her abilities and her independence. She said that they let her do more things by herself even though they still worry. When asked about the hopes and expectations that her family has for her, she replied that they want her to be happy. Even though being protective, her parents still support her to do what she truly believes she can do. She added that, "I think they know my limitations. .. . They help me a lot. They try to understand what I am going through and everything."

Mai identified her family love and acceptance as two of the most important things for a child with disabilty. She also said that parents should not be overly protective and should try to allow the child to become his/her own person.

\section{Experiences with Non-Family Members}

Mai stated that she has only a couple of Vietnamese friends. Her family and her friends' families know each other. They get together sometimes, and those are usually the only times that she interacts with many Vietnamese people. When asked about the Vietnamese people's attitudes towards her disability, she replied "I guess they accept me." She went on to say that she is more comfortable with her childhood friends because "[they] know what I can do and can't do. They are more accepting. I can walk around without my shoes and not worry about them staring." 


\section{Personal Beliefs and Motivation}

Mai described herself as follows:

I am stubborn, determined. I guess just because I have a handicap, I want to please other people, so they won't see that [I am handicapped]. You know. I don't know. Maybe sometimes I try to be more nice to people because I, I don't want them to say things about me or do anything to me because I am handicapped or something.

She said that she worries that people may just look at her handicap and not at her personality.

Mai feels that being disabled has helped her become more sensitive and compassionate toward others. However, without her disability, she thinks she would be more aggressive. Mai stated that she is pretty hard on herself; she expects the best. Her goals are to finish optometry school and to participate in more activities independently, especially the sporting activities that are difficult due to her physical limitations. She said that her disability is challenging for her and sometimes it gets her down because she can not be as independent as she wants to be.

Sometimes I see what other people are doing, like they can go wherever they want alone, and do the things alone, and I can't. I have to find someone else to do it with me, to help me, that is kinda frustrating. ... Like the canoe trip.... and the skiing trip, someone has to come along with me [to help me get in and out].

When asked what she would say to a person who has recently become disabled, she said that the person needs to know that he/she can still do the 
things that he/she wants to do, just in a different way. His/her disability can help him/her become a better person and appreciate life more. Mai identified the factors that motivate her to achieve as: (1) her family's love and support, (2) her desire to be independent and to succeed, and (3) the disabled role models within the society.

\section{CASE 2 -- Truc \\ Background}

Truc is a 27 year old single woman. Through a family unification program of the United States government, Truc's sister was able to sponsor her, her brother, and her mother to come to the United States three years ago in 1991. Truc had no formal schooling in Vietnam because her family was poor and because of her disability. Her mother sold goods in the market to support the family. Truc worked as an embroiderer since the age of 13 to the time she immigrated to the United States at the age of 24. She is fluent in Vietnamese and understands English minimally.

Truc lost the function of her legs when she was 5 years old. She does not know the cause of her disability. She recalled waking up one morning and was not able to use one of her legs. She said that the doctors gave her shots and also performed surgery on her leg but their effort did not help. She eventually lost function of both of her legs.

Truc underwent orthopedic surgery here in the United States for her leg contractures. She is presently receiving Physical Therapy three times per week at a nearby hospital. Truc is independent in her daily self-help skills. 
She does not know how to drive and said that she uses "the taxi for handicapped people" to travel to therapy.

\section{Experiences with Family Members}

Truc presently lives in an apartment by herself. She moved there about 6 months ago to be closer to the hospital for surgery and for weekly physical therapy appointments. Prior to her move, Truc was living with her mother and her younger brother, who live about 3 hours driving distance away. She also has an older sister who lives close by. Truc's father died when she was 6 years old.

It was observed that talking about her family was emotional for Truc. She described her relationship with her family as "không có thuận" (not getting along). She said that there was much sadness for her while growing up in Vietnam. When asked about specific experiences, she was not able to talk about them. She did, however, share that there was a lack of "tình thương" (love), "sự hiểu biết" (understanding), and "sự gàn gủi" (closeness) with her family. She recalled that her father was the only person who had spent time with her and gave her encouragement; he died about a year after she became disabled. Truc said that her family was poor so she had to work at an early age. As a child, she tended animals (chickens and pigs) at home, and at the age of thirteen began to work at a factory as an embroiderer.

When asked about the hopes and wishes that she feels her family has for her, she just simply shook her head sadly. She said that her older sister, who came to the United States in 1975, tries to help and encourage her more now. 
Truc said the following in regard to what parents can do for their disabled child:

Theo em thì họ [cha mẹ] phải gần gủi với đứa bé, thương yêu nó nhiều hơn tại vì nó cần sự thương yêu. Cố gắng giúp đở nó ...., thì an ủi nó nhiều hơn. Em hời nhỏ thì em không có cái đó. Em không có cái tình thương đó.... Mình nên khuyến khích nó để nó làm tự lấy, ... Đừng có nói với nơ "không" cái đó nó làm không được. Nếu nó muốn làm thì mình nên giúp cho nó làm.

(According to me, they [parents] have to be close to the child, love him more because he needs that love. Try to help him ..., comfort him more. When I was little I didn't have that. I didn't have that love. ... We should encourage him so that he can do things by himself. . . Don't say "no" to him, don't say he can't do that. If he wants to do it then we should help him.)

\section{Experiences with Non-Family Members}

When she was in Vietnam, Truc felt that the adults with whom she interacted were either helpful to or ignoring of her. In contrast, some of the young people (children and teenagers) could behave rather cruelly toward her. She said that she had some friends in Vietnam and she relied on them a lot. She described her friends as follows:

Thái độ của bạn em thì rất là tớt. Không có nóng và giúp em rất là nhiều. Em cảm thây tụi nó bảo bọc và giúp đở mình. Cái tình thương cũng giớng như một cái gia đình vậy. ... Thành ra cái tình thương đó lớn lám. (The attitudes of my friends were very good. [They were] patient and helped me a lot. [I] feel that they protected and helped me. The love is like one of a family. .. That's why that love is very big.) 
Truc said that when she moved to the United States and left her friends behind, that was a big loss for her. She has made some new friends; a few of them are Vietnamese. She stated that most of her experiences with Vietnamese people in the United States have been positive. Some tried to help her because of her disability and that had made her feel happy.

Personal Beliefs and Motivation

Most of Truc's daily activities center around the house. She said that she likes to read, listen to music, and watch cartoons on TV. She only goes out for therapy at the hospital, and sometimes with her sister when she comes by her home on weekends. She does not like to go out by herself. According to Truc, this is because she cannot walk well, does not drive, and does not speak English. Truc described her life as "cô độc" (lonely). She said that she shares her feelings mainly through her diary.

Truc often refers to her disability as "bệnh" (a sickness). When asked what she would like to achieve in the next few years, she replied "Em muôn em đi tập để hết bệnh, biết không, và trở lại đi làm bình thường thơi chớ còn ước muớn xa hơn nửa thì em không có" (I want to do therapy to get over my sickness, you know, and to return to work like usual. Otherwise, I do not have any wish beyond that). Truc could not identify a strength relating to her disability. She identifies a weakness as having to depend on other people when she needs to go out, or to do things that require strength and endurance.

Truc expressed that the love of her friends, especially those in Vietnam, is crucial to her being. She shared "Nếu em không có bạn bè thì chắc em không có sớng đến bây giờ" (If I don't have friends then probably I would 
not have survived until now). Truc said that she liked her job in Vietnam because she was one of the best embroiderers, and that had made her feel happy and comfortable. In the United States, she feels that there are many opportunities (treatment and social programs) for people with disabilities and that fact is good.

Truc said that she would suggest helping a person who has recently become disabled by (1) giving him/her lots of cheerful attention, (2) encouraging him/her to perform in therapy, and (3) helping him/her not to think about his/her sickness. "Nếu mà họ nghĩ là họ bình thường thôi thì em nghĩ họ sẻ vui trở lại" (If he thinks he is just normal then I think he will be happy again). She believes that a person with a disability needs most is love, sensitivity, and patience from others. Truc said she likes to help people because it makes her feel happy, and because being helped was lacking in her life.

\section{CASE 3 -- Huong}

Background

Huong is a 32 year old single woman who immigrated to the United States in 1981 when she was 18 years old. Huong had no formal schooling in Vietnam. When she came to the United States, she attended a year of high school. Huong is presently attending a community college close to her home where she is studying business.

Huong was diagnosed with Poliomyelitis when she was 3 years old and lost the use of her legs. She has never had surgery or therapy intervention. At the present time, she is ambulating independently mainly using crutches 
and occasionally a wheelchair. She is independent in her daily self-care activities and is able to drive a car. Huong likes to challenge herself physically. She swims, plays tennis using her wheelchair, and frequently exercises using weights. She is bilingual in Vietnamese and English.

\section{Experiences with Family Members}

Huong's family owned a welding shop in Vietnam. She is the second child in her family. Her mother died shortly after she was born and after her father remarried, she was sent to live with her maternal grandmother and aunt. Her father had other four children in his second marriage. Presently, Huong is living with her father, stepmother, her brother and his wife. All of her other siblings are married and living separately.

Sharing experiences about her childhood was observed to be emotional for Huong. She used words such as "sợ sệt" (fearfulness), "buồn bả" (sadness), "mặc cảm" (feeling inferior), "bất lực" (helpless), and "cô độc" (lonely) to describe her feelings as a child growing up with a disability in Vietnam. She recalled that her family often kept her hidden. As a result, she began to have that expectation of herself and tried to hide when visitors came to the house. Her family also kept her a secret from her siblings. Huong said that her family (grandmother and aunt) cared for her by feeding and clothing her; however, she felt a lack of sentiment and understanding from her family, and that she often was ignored.

When Huong came to the United States in 1981, she lived with her father, stepmother, and siblings. She described being in the United States as "cho em a chance để đôi diện với cuợc đời hơn" (giving me a chance to face life more). She saw many opportunities for herself as a person with disability and began a 
period of change which she called "chống đói" (rebellion). She remembered being jealous of her siblings and of finding ways to get her parents' attention, especially her father's, by buying gifts or picking a fight. She described her feelings during this time as "vui" (happy) as well as "khó khăn" (difficult). Happy because she was growing and moving toward independence and difficult because she could not find ways to be at peace with herself and her family.

Another turning point in Huong's life occured when she joined the Vietmanese Buddhist Association (in the last few years) and became an active member at a local temple. She said that she has learned from the Buddhist teachings how to "nhịn" (refrain). With this new attitude, she was able to open her mind and learn to understand her family members, and is able to live with them in harmony.

With the independence that she has gained, Huong described herself as being important, visible, and needed by her family. "Gia đình thåy mình làm được này nọ thì. . . bởi vậy họ mới thấy mình quan trọng" (seeing that I could do this and that. . .that's why they began to see me as important). When asked what are the expectations that she feels her family has of her, Huong replied, "Không có, cũng như là họ không có nghĩ em sẻ làm cái gì được" (Nothing, it's like they don't think [I] will be able to do anything). However, Huong does feel that this attitude has improved through time. Even though her family does not encourage her, they will accept and allow her to pursue her goals.

When Huong was asked what she would say to a Vietnamese couple who had a child with disability, she said that the most important thing for this couple to give such a child is love. They should give the child attention and 
learn to understand him/her. Because of his/her handicap, he/she probably would have lower self-esteem and be more sensitive. A must would be to teach him how to live independently, otherwise, he will always feel fearful and uncertain.

\section{Experiences with Non-Family Members}

Huong explained that in Vietnam, because of the cultural stigma against individuals with handicapping conditions, she mainly lived in isolation and did not have friends. In 1975, after the war, her family moved to the city (Saigon). Huong started to do more things around the house and also got out more. She began to know the neighborhood children. She said "Mình lôi cuốn được bạn bè. . . nhưng mà không phải tại vì nó thương yêu mình hay là hiểu biết về mình" (I was able to attract friends. . . but it was not because they liked me or understood about me). She felt that they became her friends because her family is better off financially and she can give them things. She used the term "mua bạn" (buying friendship).

Huong described her attitude when she first moved to the United States as follows:

Lúc mới qua đây thì em sẳn sàng chiến đâu với bất cứ ai. Họ đở em, em cũng khơng có chịu nữa. Em nói em không phải là bị tật, em có thể làm lầy. . . . Những cái ý nghĩ đó làm mình rất đau khổ. Ai nhìn mình cũng sợ. Thành ra mình cứ đẩy người ta ra, trớn trong cái thế giới riêng của mình. (When I just came here [United States], I was ready to confront with anyone. They tried to support me [physically], I wouldn't let them. I said that I was not handicapped. I could do it myself. . . . Those kinds of thoughts made me feel painful. I was afraid of anyone who looked at me. Because of 
that, I kept pushing people away, hiding in my own world. I built it to protect myself.)

A few years later, she joined a Vietnamese Buddhist Temple and became an active member. She shared that this was the turning point in her life. With her study of Buddhism and the support of temple members, she learned to accept her disability and became more open to other people. She said that it is easier for her to make friends now. Huong feels that the Vietnamese people at the temple do not look at her with "con mắt tò mò" (eyes of curiosity) but they "chia xẽ cái tình thương thật tình" (share their genuine love and care). Huong takes a lot of pride in her leadership role with the youngsters at the temple. When asked how a friend would describe her, she cheerfully shared a story about a little girl at the temple who had written a poem for her that said wonderful things about her. Huong described her feelings now as "không sợ đối diện với người ngoài" (not being afraid of facing other people), "vui vẽ" (happy), "không có mặc cảm" (not feeling inferior), "important", and a sense of belonging.

Huong said that when she is doing things outside the temple in the Vietnamese community, she feels that people do not pay much attention to her. She can do anything she wants to do.

\section{Personal Beliefs and Motivation}

Huong describes herself as "cứng đầu" (stubborn). She has gone through many changes in her life. She feels that her stubborness along with her "mặc cảm" (feeling of inferiority) have helped her overcome obstacles and find ways to improve herself. 
Cái mặc cảm của mình cũng làm cho mình đau khở nhưng cái đó cũng là một cái sức mạnh để mà thúc mình lên, . . . e, em muốn show người ta ràng em muốn làm cái gì cũng được, $\ldots$, mình mà nhờ vả người ta quá thì mình belong cho người ta. (My feeling of inferiority had made me feel painful but it also had given me the strength to do better, . . . I I want to show people that I can do anything I want to, .... if I have to depend on people too much, I will belong to them.)

Huong sees herself as changed from being scared, useless, sad, and unaccepted to being independent, able, needed, important, happy, and accepted. She talked about how the support she received from her study group at the Buddhist temple and the opportunities available for individuals with handicaps in this country have helped her. Huong identified many factors that had helped motivate her to achieve. These included the strong desire to be independent, the love of her family and friends, the need to feel safe, respected, and useful, the social opportunities available, the role models within the community, and buddhism.

When asked what she would suggest to help a Vietnamese person who recently was injured and became disabled, she said her first suggestion would be to have patience. Take time to learn and understand this person because each individual copes differently. One needs to help the person find a light, a road to acceptance, independence, and be a needed member of society. That is when a person can go on. She feels that the person's family probably will have an important impact on him. Nevertheless, the most important thing is that the person must help himself. The person must have "strong mind" 
and "ý chí phấn đáu" (a will to fight). Huong thinks that people with disabilities will need the help of "normal" people more because "[Họ] không dám nhìn những người có handicap tại vì [họ] sợ thây [họ] ở trong đó" (They do not want to look at people with handicaps because they are afraid of seeing themselves).

\section{CASE 4 -- Thuy}

Background

Thuy is a 34 year old single woman who had poliomyelitis when she was 15 months old. She participated in therapy programs both in Vietnam and a special program in Germany for about a year. Thuy had formal schooling in Vietnam until she emigrated to the United States in 1978 at the age of 18 . She continued with schooling here and graduated in 1984 with a degree in Engineering. She worked at IBM for about 9 years before returning to school. She is presently in her first year of medical school. She said that she would like to be able to help people.

Thuy uses crutches, sometimes with braces on her legs. She is able to drive a car and is independent in her daily self-care activities. She feels the daily activities that require much physical strength and stamina are more difficult for her. For example, she cannot carry heavy objects and is not able to stand for an extended period of time. She does not participate in physical leisure activities. She enjoys listening to music, playing the piano, reading, writing, and attending cultural events. Thuy is bilingual in Vietnamese and English. 


\section{Experiences with Family Members}

Thuy presently lives independently in an apartment close to her school and returns to her family's home in San Jose on the weekends. Presently the people who are living at home are her grandparents, her older sister and her sister's husband. Her father is a physician and due to his work, he and his wife live in another state. Thuy has a total of three siblings--an older sister, a younger sister, and a younger brother.

Thuy described her parents as having "ý hướng mà bảo vệ mình nhiêu hơn là những đứa con khác" (the inclination to protect her more than the other children). She remembered the sibling rivalry in her childhood that resulted from jealousy of the fact that her parents spent more time with her. Thuy stated that her parents did not have expectations for her. She said "[bó mẹ mình] nhìn thây những cái limitations của mình, thành ra không có bắt buợc mình phải tranh đáu" (my parents saw my limitations, that's why they didn't expect me to struggle). They just wanted her to be happy.

Thuy feels that many of the goals that she has achieved are largely due to her own determination, not the expectations of her family. She often sets challenges for herself as opportunities arise.

Thuy observed that the attitudes of her parents' and her siblings' regarding her disability have changed through the years. She thinks that everytime she overcame a challenge and achieved a goal, her family gained more confidence in her abilities and allowed her to be more independent. Her mother sometimes expresses that she does not want her to "có gắng quá nhieu" (try so much). She is concerned that Thuy is too hard on herself; she is setting up too many challenges for herself. 
When asked what advice she would give to a Vietnamese couple who has a child with a disability, Huong said that in order for the child to develop fully, the support, love, and patience of his family is most important. Thuy cautioned that parents also need to help the child overcome challenges and gain something of his/her own. Over-protectiveness can prevent the child from achieving independence. She described the child as "món quà từ thượng đê" (a gift from God).

\section{Experiences with Non-Family Members}

Thinking of her experiences in Vietnam, Thuy recalled that the people were not very "cởi mở" (open or friendly) toward people with disabilities. She felt that the people had "nhan dạo" (humanity) but they did not have an understanding of disability. Disabled individuals did not have a voice there. Thuy said that she tried to "hoà đông" (get along) with her peers at school but it was difficult. She expressed that "những người bì tật thì có ít người muớn làm bạn hon" (those who are handicapped have fewer people who want to become their friends).

Thuy stated that in American society, there are more explicit laws to help and protect people with disablities. Also, she recognized that there is more effort to educate people about handicapping conditions so that awareness within the general population is heightened. When asked about her experiences with Vietnamese people in the United States relating to her disability, she replied that she feels "thoải mái hơn" (more comfortable) here. Her experiences with Vietnamese people have been varied; there are people who are overly "ân càn" (obliging) where others lack "tế nhị" (sensitivity). Nevertheless, she feels that there are more positive than negative 
experiences, and that the Vietnamese people here are more open and accepting, probably because they have assimilated into the new society.

Regarding her Vietnamese friends, Thuy said, "Đối với những người bạn mà quen biết từ lâu rồi thì hình như họ không nhận ra là có sự khác biệt và là mình đi nạn hay khong nửa" (regarding friends that I have known for a long time, it seems like they do not recognize that I am different and that I am using crutches).

\section{Personal Beliefs and Motivation}

Thuy used words such as "cô lập" (isolated), "phấn đáu" (strong will), "vui vẽ" (happy), and "thích ứng" (adaptable) to describe herself. Thuy responded to the question regarding her personal beliefs toward disability as follows:

Tơi nghĩ bất cứ những đî̉u gì trong đời sớng cũng có những cái ... . gióng như không có chuyện gì quá tớt và không có chuyện gì quá xấu. Thành ra ở trong bất cứ hoàn cảnh nào thì mình cũng get out được cái positive nếu mình muớn nhìn thấy đễu đó. Cái quan niệm của tôi về disability đĩ nhiên là không phải mình lựa chọn láy. Cái đó là một điều nó đến. Thành ra mình chỉ có thể cớ gắng để mà mình get out the most positive of the situation. (I think in life there is .... it's like nothing is too good and nothing is too bad. That's why in any circumstance, we can get something positive out of it if we want to see it. My personal belief about disability, of course, is that it's not what I choose for myself. It is something that happens to me. That's why I can only try to make the most out of the situation.)

Thuy feels that her disability, in a way, is a blessing for her. From being disabled, she has learned to be compassionate, sensitive, more forgiving, 
patient, and emotionally stronger. She thinks that two of the most important things to help a person with a disability are (1) a will to improve oneself and (2) the love of his/her family. With these, the person can break through any barriers and learn to be "tự tin" (confident) through accomplishments. Also, having a role model and sharing experiences with other disabled people are also helpful. She described this country as "đất của cơ hội" (the land of opportunities) for people with disabilities.

A negative influence regarding her disability, she thinks, is that perhaps it has influenced her in choosing a life style that is more isolated. She sometimes feels that it is difficult to mix with the "normal" peers. Overall, she feels that there are more positive than negative experiences relating to her disability. By focusing more on the positive, it has helped her to lead a more peaceful life. Thuy identified the love of her family as one of the motivational factors for her. Other motivational factors include the strong desire to succeed, the social opportunities available, the role models within the community, and God.

\section{CASE 5 -- Minh \\ Background}

Minh is a 47 year old married man. He and his wife have been in the United States for about a year and a half. Minh said that in Vietnam, because his family was poor, he only attended elementary school before going to work and to help his family.

Minh explained that he lost his legs (above knee amputation) during the Vietnam war in 1973. He can ambulate independently using a manual 
wheelchair or moving about on the floor using his arms. He is independent in his daily self-help skills. Minh enjoys gardening, some carpentry work, and watching television. He speaks Vietnamese only and does not drive.

Experiences with Family Members

Minh was married when he was 19 years old and has been happily married since. He has four sons, two of whom immigrated to the U.S. in 1983. His sons were able to sponsor the rest of the family over to the U.S. through a family unification program. Before coming to the United States, Minh worked at a factory polishing lacquer goods. Minh and his wife presently live with their four sons. Two of them have graduated from college. His eldest son is considered to be the "bread winner" of the family.

Minh shared that an overwhelmingly positive outcome resulting from his disability is realizing the love that his family has for him.

Nhờ cái tật nguyền rời mình thấy vợ con nó đới đải với mình tớt á, tự nhiên mình thây cái sự thích sống của mình tăng thêm, bởi vì mình thấy cái giá trị của cái tình thương của vợ con .... Nhờ cái này [tật nguyèn] mà tôi biết được cái tình nghĩa sâu sắt của vợ tôi, với cái kính nể mà con cái nó dành cho mình. (My disablity has helped me see how well my family treats me, suddenly, my will to live increases because I see the value of the love of my family .... Because of this [disability] that I know the unending love of my wife, and the respect that my children have for me.)

Minh often expressed how proud he is of his sons, and the love and gratitude he has for his wife. Because he never had a chance for a full education, and because he believes education is one of the most important 
things for success and to be respected in life; he encourages his children to study hard.

When asked about the wishes and expectations he feels his family has for him, Minh answered "Vợ con tôi á, nó chỉ mong muốn cho tôi khoẻ, vui vẽ" (My family, they just wish me to be healthy and happy). He stated that his family worries when he engages in physical activities, such as gardening, because they are afraid that he is going to be tired. He added that this was not the case before he lost his legs; he could do anything and no one would be concerned. Despite these worries, through much convincing, Minh managed to get his family to allow him to do some of the physical activities that he enjoys like gardening, and building tables and shelves. He also added that his children do not want him to work for wages because they can and want to support him and his wife financially. He expressed "Con cái mà nó lo nghĩ cho mình như vậy thì cái cuộc sóng của tôi nó cũng bình thản" (Because my children are concerned about me like that, my life is peaceful).

\section{Experiences with Non-Family Members}

Reflecting back to when he was in Vietnam, Minh described the people as "kỳ thị" (discriminating). He went on to say "Những người mà tàn tật như tôi chẳng hạn mà còn ở Việt Nam thì rất là khổ. Có thể nói là cái chết mà dể dàng thì cái chết hay hơn" (For those who are handicapped like myself, if they still live in Vietnam, then they are miserable. One may say that an easy death is better). He feels that individuals with handicaps in Vietnam do not have a place in society and have to rely solely on their family for support or become a beggar. Nevertheless, he does think that some people in Vietnam have humanity and are concerned about people with handicaps. Their way of helping is to 
give them money. He recalled experiences when he was out in the community, some people thought that he was "người ăn xin" (a beggar) and tried to give him money.

Minh said the experiences that he has in the United States are generally more positive. The United States government has many programs to help people with disabilities to have a better life; this fact has helped him feel "an ủi" (comforted) somewhat. Minh is a frequent attendee of the Vietnamese Buddhist temple close to his home; therefore, most of the people he knows are from this temple. Of those that he knows well, he feels that they are genuinely caring and loving toward him and his family. For those he does not know well, besides casual conversations, people generally live their separate lives. They do not seem to pay much attention or show concern regarding his disability.

\section{Personal Beliefs and Motivation}

Minh feels that his disability has given him the ability to be more compassionate, and has helped him realize the extent of the love that his family has for him. He also feels that his disability is a big loss for him because a man has many responsibilities to his family, and after becoming disabled, the ability to fulfill these responsibilities are lost. Minh shared that he previously had "tự aí" (a low self-esteem), and felt "bươn" (sad), and "tủi than" (sorry for himself), mainly because he was unable to provide for his family. But through time, the love and respect of his family have helped him overcome these feelings and learn to accept himself and be happy. He said that his participation at the temple also has had an influence on his outlook 
on life. Now he describes himself as "vui vẽ" (happy), "phúc đức" (blessed), and "thoải mái" (comfortable).

Minh responded to the question "How do you think a Vietnamese friend of yours would describe you?" by:

Tôi có thể nói là họ thấy tôi bị tật nguyền qua đây [Mỹ] chỉ có việc nhờ con và vợ nuơoi thôi. Chỉ có nhờ con thôi. (I can say that they see me as disabled, came here [U.S.] and just depended on my children and my wife to take care of me. Just dependent on my children. )

Minh said that besides going to the temple, he does not go out much. Sometimes when he goes to the Asian grocery stores with his family, he would like to talk with the people, but he feels it is difficult because of his disabling condition and limited english abilility. He expressed "Lúc mà tôi bình thường mà nguười ta nhìn tôi với con mắt đó thì không sao hết. Bây giờ mà tôi như vậy, cũng cặp mắt đó mà mình lại thấy khác" (When I was normal, if people looked at me in a certain way, it is fine. Now that I am like this, that same look makes me feel different).

When asked what would he do to help a Vietnamese friend who had recently been injured and had become disabled, Minh said that first, he would "an ủi" (comfort) and "thương" (love) this person. He would tell this person not to worry about his life because this is the place where there are many programs to help people with disabilities; he can live a good life and be happy. Minh also said:

Kiếm cách giải trí như là đọc báo hay xem TV để cho qua ngày vậy thôi. Cái thời gian còn lại sau khi mình tật nguyền rồi thì đừng có mong gì, đừng hy vọng gì. Kêu gọi họ, an ủi họ như vậy thôi. Chứ bây giờ làm gì đây. (Find ways to 
entertain himself such as reading newspapers or watching TV for the day to go by. The time that is left after one is disabled, don't wish for much, don't hope for much. Encourage this person, comfort him, that's all. What can you do.)

For a child with disability, Minh feels that the love, care, and sensitivity from the family are most important for his/her development. He thinks that the disabling condition is a consequence of the child's previous life. It is a punishment for wrong doings of the child or of his family. He indicates that the parents need to accept this consequence and overcome their sadness to love and to educate this child. According to Buddhist teaching, individuals whose fates are less fortunate need to be loved even more than those who are fortunate. Therefore, Minh feels that people need to love the disabled child to help alleviate his/her sufferings and assist him/her toward a happier next life. He recommends that the child learn a trade that fits his ability so that he will be able to help himself and contribute to the society when he grows up.

Minh identified the love of his family and friends, the desire to be useful, the need to feel important, the social opportunities available, and Buddhism as factors that motivated him to strive toward self-improvement.

\section{CASE 6 -- Quan}

\section{Background}

Quan is a 54 year old married man. He has been married for 25 years and has 3 children. He and his family immigrated to the United States in 1983. 
Quan attended college in Vietnam and is fluent in Vietnamese, English, and French. In Vietnam, he worked for an American company as a translator.

Quan suffered a stroke in 1972 when he was 30 years old. His stroke left the right side of his body paralyzed and he lost of his ability to speak. He participated in physcial therapy initially in Vietnam but said that the techniques were too painful, and so he decided to practice walking on his own at home. Quan eventually was able to walk independently with a limp. He also regained his speech and minimal function of his right arm. Quan is independent in his daily self-help skills and can drive a car.

Experiences with Family Members

Quan's oldest child is in college and the youngest one is in elementary school. All three are still living at home. Quan's wife works full-time as a beautician and is the "bread winner" of the family. Quan's role is to take care of the household chores and to help educate his children.

Quan shared that his family relies on him very much. He said "Vọ tôi và con tôi nó cần đến cái sự hoạt động của tôi [trong đời của họ]" (My wife and my children, they need my participation [in their daily lives]). Quan drives his children to school and his wife to work daily. He also cooks all the meals and tends the yard. Education is very important to him, and he spends considerable time teaching and helping his children with their school work.

Quan described his family's attitude toward him as "kính nẽ" (respectful). He emphasized that he continues to be the decision maker in the family. He expressed that his family loves him even more now than before his stroke because they see that he cannot do some of the things that they can. 
Quan shared that his children, especially the youngest, are protective toward him. He said that his youngest daughter often monitors his activities (ie. fixing the car, mowing the lawn, etc.) and gets very upset if he is tired or has injured himself. His wife was described as less protective because she understands his abilities and understands that he likes to be independent.

\section{Experiences with Non-Family Members}

Quan feels that people in Vietnam are not educated about persons with disabilities and they have the belief that if a person is disabled, he cannot do anything but "làm người ăn xin" (be a beggar). In regard to Vietnamese people whom he has met here in the United States, he said that some of them may have reservations in the beginning but after they get to know him, they respect him more. He also shared the following thoughts:

Tôi không hiểu cái thái độ của họ như thể nào tại vì họ không có cái gì chứng tỏ cả (I do not understand what their attitudes are because they do not show much).

and

Dù sao đi nửa người Việt qua đây mười mây năm, at least ... họ cũng thấy rằng mình phải kính nể những người handicap. (After all, Vietnamese who have been here many years, at least ... they recognize that they have to respect people with handicaps).

Quan also feels that the level of education a person reaches is one of the important factors shaping the person's attitude toward people with disabilities. Regarding long time Vietnamese friends, Quan thinks that they do not see him as being disabled. He feels that they care for him and respect him. 


\section{Personal Beliefs and Motivation}

Quan shared that before his stroke, he was an energetic, aggressive young worker, and that he liked outdoor activities. He had to make many adjustments with his life style after his stroke. Quan described himself now as adaptable, "nhường nhịn" (yielding), and "vui vẽ" (happy). His goal is to educate his children and his hope is for them to succeed.

Quan expresses that his disability has made many daily tasks difficult for him; however, he likes to do as much by himself as possible because people are not always there to help him. He said "Sửa xe, xếp quần aó, cái gì tôi làm được thì tôi làm. Thí dụ như cô để cho tôi thì giờ cho tôi làm thì tôi làm được hết, chỉ không có 100 phàn trăm thoi" (Fixing cars, folding clothes, I do whatever I can. If you allow me time, then I can do everything, only that they are not 100 percent). He found that his disablity had helped him become much more creative in his problem solving skills, figuring out different ways to do tasks one handed.

Quan said that after his stroke in Vietnam, he was able to return to his old job with the American Company. Having his job back had helped increase his self-esteem because he felt that he still "co chan trong society" (had a place in the society). When he came to the United States, he found that his language skills were not needed and that he could not find a job. He eventually became discouraged and stopped looking. He shared an experience where he was offered a part time job at his child's school to translate and he refused. He said "Tôi nói rằng tôi không nghĩ tôi làm được việc đó. Tôi không biết tại sao. . . Có thẻ̉ tôi nghĩ rằng là tại vì handicap" (I said that I could not do that job. I didn't know why .... Maybe I thought of my handicap). 
When asked what would he say to help motivate a person who had just recently suffered a stroke, he said that he would use himself as an example to show the person that a disabled person can be independent. He said "Đói với mình [người tật nguyền] sẽ không hoàn toàn, nhưng vẫn đạt được nhî̃u mục đích mà mình muón" (We [persons with disability] will not be perfect, but we can still achieve many goals that we want). He would encourage the person to fight. In addition to role models, Quan also identified the love and respect of family and the desire to be independent as other motivational factors.

\section{Results and Discussion of Research Questions}

The data from the six cases were analyzed for the emergence of patterns or themes in attitudes of Vietnamese toward persons with physical disabilities, and in the motivational factors observed in the psychosocial adjustment and self-improvement of Vietnamese persons with disabilities. Results and discussion are presented for each research question.

The researcher found that because of the small sample size and because the backgrounds of the subjects were so varied, only a limited number of themes that were common to all of the six cases in the study were identified. The researcher believes that even though some of the themes emerged only in some of the cases, they are valuable information warranting discussion. For this reason, the results also include themes that are common in only 4 or 5 cases of the total 6.

Furthermore, Mai's case was eliminated from the analysis for attitudes of non-family members because Mai has very little contact with Vietnamese 
people outside of her family and was unable to provide much information. Mai's case was included in the analysis of other research questions.

\section{Question One}

As perceived by Vietnamese individuals who are physically disabled, what are the attitudes of family members toward them?

After extensive analysis of the data, the researcher was able to identify only one theme that is common through all six of the cases regarding the attitudes of other family members toward the member with a disability. This theme is "conservative expectations." Another two themes, "protectiveness" and "attitude of loving and caring," are also identified which are evident in 4 of 6 , and 5 of 6 cases respectively.

\section{Conservative Expectations}

Tại bố mẹ tôi nghĩ ràng về sau này thì nhều khi tất cả những người con khác nó trưỡng thành, lớn lên mổi người đi một ngã đó, ... Nếu tôi thích được âm nhạc thì cũng là một đî̉u vui riêng của tơi đó. Thành ra bớ mẹ cũng cớ gắng để tạo ra một mơi trường mà thích hợp đới với mình. . . Tại vì nhìn thây những cái limitations của mình, thành ra [bó mẹ] không bắt buột mình phải tranh đấu nhiều. (Because my parents think that later on when all the other children are grown and going their separate ways, ... If I like music then it will be my own happiness. That's why my parents tried to create a situation that is compatible for me... Because they see my limitation, they do not expect me to strive for things.) Thuy. 
and

Khi mà mình còn chân thì mình làm gì thì làm, không ai nói gì hết. Nhưng mà sau này mình mất chân rồi thì vợ con không muốn mình mệt. (When I still had my legs I could do anything I wanted, no one would say anything. But after I lost my legs, my family did not want me to be tired.) Minh.

Whether it is with academic achievements, career goals, household chores, or leisure activities, all of the participants expressed that their family members placed more conservative expectations on their potential. The family has the attitude that the family member with a disability should not work hard, mentally and/or physically. Both Thuy and Mai mentioned that their parents think they are too hard on themselves by setting many difficult academic challenges. Quan shared situations when he engaged in chores that required physical exertion, such as fixing the car or mowing the lawn, that his children would often monitor him with concern even though he is very capable of doing these tasks. Minh reported that he likes to keep active by doing simple carpentry and gardening work. Although he lost his legs, his arms are unaffected and he can move about quite independently, thus, his disability does not prevent him from participating in leisure activities. Despite his ability, his family allows him to participate only after much persuasion and only in moderation. His family encourages him to engage in less physical leisure activities such as reading and watching TV.

Another attitude relating to the abilities of persons with disabilities is the perception that they lack the capability to learn. This attitude was evident in the cases of Huong and Truc, especially when they were in Vietnam. Even 
though Huong's mental ability is unaffected by her handicapping condition (poliomyelitis), she recalled that while growing up, her family did not attempt to educate her or talk much with her. She described her activities as sitting around, eating, and sleeping. Huong said that this attitude has improved a great deal through the many years that she has lived in the United States. However, even with the evidence of her achievements, her father continues to have lower expectations for her. For example, when Huong approached her father about the idea of attending a business program at a Community College, he refuted the idea by saying "Học hành làm cái gì rồi ra cũng chẳng làm được cái gì hét." (Study for what? And when you graduate you still cannot do anything.) Truc, another young women who is very competent mentally, indicated that her mother has no expectations for her and does not encourage her to try anything.

Protectiveness

They [parents] don't let me do certain things that I want to do . . . They did not let me drive until I moved out of their house to go to school. They are always very protective. . . . Like the things that my siblings can do, but if I ask them if I could go out ... with my friends, then they would let my siblings but they wouldn't let me. Mai.

This theme is reflected in 4 of the 6 cases. With the family's attitude of "conservative expectations" and their love for the disabled members, many of the disabled persons' families exhibited protective behavior toward them. 
The level of protectiveness ranged from simply showing concern to actually trying to prevent the disabled individual from doing something that they want to do.

\section{Attitude of Loving and Caring}

Họ [gia đình tơi] thương tôi rất nhiều. Hởi đó họ thương tôi 50 phần trăm, nhưng giờ [sau khi tôi bị stroke] thì họ thương tôi 100 phàn trăm. (They [my family] love me very much. They used to love me 50 percent, but now [after my stroke] they love me 100 percent.) Quan.

and

I guess they [my family] accept it [my disability]. They try the best they can to try to raise me, and ... they just try to understand what I need and help me. Mai.

Although varying in degrees, it is evident in 5 of the 6 cases that the disabled members feel their families love and cared for them. Minh expressed that he is a very lucky and happy man because his wife and children have surmounting love and respect for him, in spite of his disability. Along the same lines, Quan often talked about the love, caring, and especially the respect that his family has for him. He appeared to be happy with the switch from being the provider, a traditional role of a male member of a Vietnamese family, to that of a caretaker of the children and the household. He feels that his family accepts and needs him to fulfill this role. Both Mai and Thuy expressed a sense of unconditional love and acceptance toward them from their parents and siblings. Their siblings were described as treating them "normally" and having "normal" sibling quarrels. 
Huong did not feel the love and attention of her family until she was in her adult years. She lost her mother at a very young age and when her father remarried, she was sent to live with her grandmother. She expressed that while growing up in Vietnam, she felt a lack of love, attention, and understanding. She is now living with her father and stepmother in the United States. After many years of learning about herself, and trying to know and understand her family, she now describes her relationship with her father and her stepmother as close and loving.

Summary and Discussion of Question One

According to the emergent themes, these persons with disabilities perceived their families' attitudes toward them as loving and caring but often with less understanding about their abilities. The families placed more conservative expectations for the individuals regarding their achievements and independence. With the concern that the disabled persons may not be able to handle the challenges of certain situations, they attempted to help or to protect their disabled family members by discouraging them or sheltering them from meeting those challenges.

Most of the participants indicated strong bonds with their families; however, they expressed that their families' attitudes of protectiveness and conservative expectations may hinder but do not prevent them from achieving their goals. All of the participants shared that their present level of independence and the things that they have accomplished so far are largely due to their personal determination, not the expectations of their families. The participants indicated that their desires to master a task and their stubborn personality trait are the major factors that influence the attainability 
of their goals. The participants also feel the love and caring attitudes of their family members, as well as the opportunities available within the American society, give them security and provide them with the courage to face challenges.

The participants in the study recognized that their families' attitudes have changed through the years. As the persons with disabilities demonstrated and proved their abilities, they noticed that their family members became less protective and more supportive of the goals that they set for themselves.

\section{Question Two}

As perceived by Vietnamese individuals who are physically disabled, what are the attitudes of non-family members toward them?

Due to the complexity of the data received in the area of attitudes of nonfamily members, the researcher organized the themes into two categories: (1) perceived attitudes of non-family members in Vietnam, and (2) perceived attitudes of non-family members in the United States. Even though the aim of the study was to explore the attitudes of Vietnamese people in the United States, reporting the perceived attitudes of people living in Vietnam would enhance the readers's understanding of the perceived attitudes of Vietnamese people living in the United States. Data from 5 of the 6 cases were used for the analysis in this area.

A theme identified for attitudes of people in Vietnam is "lack of understanding"; and the themes for attitudes of non-family members in the United States are "increased awareness" and "indifference and helpfulness." 


\section{Lack of Understanding}

Họ [người ở Việt Nam] không thấy ràng cái handicap đó, ông đó có thể làm được công việc đâu. Bởi vì cái quan niệm và cái hiểu biết của người Việt Nam [về sự tật nguyè̀n] rất là yếu. Cái tàn phế, tàn tật là ra làm sao. Cái lý do họ không cần biết. [Họ thấy] ông này tàn tật thì họ thây cái tàn tật là ở trong một cái class khác trong society. (They [people in Vietnam] do not see that handicapped person, that man is capable of doing any work. Because the beliefs and the understanding of Vietnamese people [about disability] are very limited. Disability, handicap, what are their meanings? They don't care about the reasons. [They see] that this man is handicapped then they see the handicap as being in a different class in society.) Quan.

All five of the cases show the theme "lack of understanding" for the attitudes of people in Vietnam. The subjects perceived people as having limited understanding of disabling conditions and about people with disabilities.

A common misconception is that disabled persons are not capable and/or can not contribute to society. Minh shared experiences in Vietnam where people stopped him on the street and tried to give him money. They thought that he was a beggar. Minh is a very capable person in spite of his disability; nevertheless, these people's actions indicated that they see Minh in the context of his handicap and that he must be helpless, incapable of working, and perhaps miserable.

With limited understanding about persons with disabilities, many youngsters in Vietnam see disabled people as strange, helpless, and 
undesirable. Four subjects shared experiences of being treated differently or sometimes being ridiculed by some youngsters. Thuy attended a prestigious high school in Vietnam. She described her experience as having a difficult time mixing in and thus became isolated. Huong managed to make some friends in her neighborhood in Vietnam; however, she felt that she must constantly "buy" their friendship. Truc and Minh encountered youngsters who were lacking in sympathy and behaved cruelly toward them because of their disabilities.

Thuy added that people with disabilities in Vietnam comprise a minority group that has no voice. The society is not open toward people with disabilities and because of lack of understanding regarding their abilities, it discriminates against them, does not pay attention to their needs, and does not create special social programs to help them.

\section{Increased Awareness}

Ở bên này $[M \bar{y}]$ tôi cũng nhìn thây rằng cái phương diện giáo dục thì . . . có khi được explicitly explain về những trường hợp bị tật đó và không nên đối xử với họ một cách khác biệt hơn. (Over here [United States], I observed that in regard to education ... sometimes explicit explanations are given about handicapping situations and that one should not behave differently toward them.) Thuy.

The theme of "increased awareness" is evident in all of the five cases analyzed regarding the attitudes of Vietnamese people in the United States. The subjects reported that people, especially those who have lived in the United States longer, appear to be more informed about handicapping 
conditions or at least became more aware that disabled people should not be treated differently. Vietnamese people in the United States may be more aware of the rights of disabled individuals as a result of exposure to specific programs and laws designed to assist people with disabilities. With certain degrees of assimilation to the American ways of perceiving disabilities, Vietnamese people in the United States adopt a more open attitude. Indifference and Helpfulness

Thí dụ như em đi chơi, cái xong ra tới một chổ nào đó, . . . . em đi không được . . .

. Có nhiều anh chị trong nhóm rất thương đó, không muốn bỏ rơi em, cỏng em di. (For example, when I went out on an outing, and then came to a certain spot, . . . . I couldn't go anymore. Some of the people in the group really cared about me, not wanting me to be left behind, and carried me on their backs.) Huong.

and

Ở trong chùa chiền . . . họ không có nhìn mình với một con mắt tò mò . . . Còn người ở ngoài [chùa], ... họ không có để ý đến mình nhiêu giớng như xưa [ở Việt Nam]. Ai muốn làm gì thì làm. (In the temple ... people do not look at me with eyes of curiosity .... With regards to people outside [the temple], . .. they do not pay much attention to me as they used to [in Vietnam]. People do whatever they want.) Huong.

The theme "indifference and helpfulness" emerged in all of the 5 cases. The subjects generally described the attitudes of Vietnamese people in the U.S. toward them as either indifferent or helpful. Three subjects indicated that there are "người xấu và người tớt" (good and bad people) anywhere a person 
goes; however, in general, their interactions with Vietnamese people in the United States have been more comfortable than in Vietnam. Some people do not appear to pay much attention to them at all while others try to assist them. It is unclear whether the indifference attitude is a result of increased awareness of how persons with disabilities should be treated or because people view the disabling condition as a secondary characteristic not warranting their attention. Truc thinks that the American society is too fast paced and people just do not have time to pay attention to other people. According to Thuy, some people are overly helpful which is unnecessary.

For both Minh and Huong, their experiences with Vietnamese people in the United States have been mainly through the temple in which they are active members. They have developed special bonds with many of the people at the temples and feel that they genuinely care about them. For the people outside the temple, both subjects said that they appear not to pay much attention to them. Minh also shared that since he has been in the United States, he has not encountered anyone who openly ridiculed him. Summary and Discussion of Question Two

The subjects' perceptions of people's attitudes toward persons with disabilities in Vietnam fell mainly under the theme "lacking understanding." Because of limited knowledge about handicapping conditions and perhaps because of their cultural beliefs and values regarding disabilities, misconceptions may be adopted. They may believe that persons with disabilities are unemployable, uneducatable, are not well-adjusted or of sound mind. These beliefs in turn shape the way the general public interacts with persons who have disabilities. Society pays little attention to the well-being of 
these people and ignores them. Some people, especially some of the youngsters who lack sympathy and understanding, ridicule them.

Minh and Huong believe that persons with disabilities in Vietnam must depend on their families for financial support. Without family members to take care of them, many became beggars and were unable to support themselves. Thuy feels that opportunities for people with disabilities in Vietnam are few. Education and the type of jobs available to them are very limited. Many disabled persons were able to function only within the boundaries of their family. Minh, Quan, and Truc expressed that people often judge a person's disability by his or her appearance. If a person is physically disabled, he or she is automatically seen as incapable and unsound. Quan often mentions about status loss of persons with disabilities. Status is highly valued in the Vietnamese culture. All three participants worked outside of their homes in Vietnam. However, Minh and Truc feel that they can only hold low level jobs, and Quan feels that he was able to return to his old job because of the history he had with the company and the people there.

Three of the five subjects pointed out that people in Vietnam do have humanity, but because of limited understanding and economic constraints, the government has few programs to help people with disabilities. For those who attempt to help people with disabilities, it is usually in the form of "hand-outs."

The most prevalent perceived difference in attitudes of Vietnamese people in the United States to the attitudes of Vietnamese people in Vietnam is "increased awareness." The subjects attributed this increased awareness toward persons with disabilites to the following: (1) American society is 
more open or perhaps more tolerant toward persons with disabilities; and (2) programs and laws are designed especially to help persons with disabitites. Because of the above two factors, a disabled person in the United States is more likely to be a member of the work force and to participate in the educational system, even in higher education. These people serve as role models for Vietnamese disabled individuals as well as for the general Vietnamese population.

Vietnamese people who have adopted a more accepting attitude toward persons with disabilities or who have a better understanding of disabling conditions, are more willing to get to know and to help persons with disabilities. This increased awareness and exposure to disabled persons in turn help alleviate misconceptions. In the United States, Vietnamese people's attitudes are perceived to be more accepting, supportive, or merely indifferent. Several of the subjects feel that the availability of social opportunities and the increased openness of the public toward persons with disabilities in the United States have given them the avenue to achieve their goals and move toward self-improvement.

One of the subjects (Huong) pointed out the observed change in attitudes of Vietnamese people in the United States can mean that they have learned more appropriate ways of interacting with individuals with disability instead of an actual change in the perception of the disabled person's worth and abilities. For example, a person may learn that he or she has to treat a person with disability kindly even though he or she continues to believe that the disabled person is incapable and unsound. 
Most of the subjects' experiences in the United States have been positive; however, the subjects indicated that whatever race or society a person lives in, there will always be a mix of people who will react differently to people with disabilities; some positively and some negatively. Quan perceived that the level of education affects a person's attitude toward people with disabilities. He said "Nếu người kia học nhiều họ biết tất cả handicap không phải là ăn xin, và người không có học thì họ nói, ah! same thing [as beggars]" (If that person is educated, he/she knows that not all persons with handicaps are beggars, and a person who is uneducated will say, ah! samething [as beggars]). The participants also commented that the amount of exposure people have to persons with disabilities influences the perception and attitudes they have toward persons with disabilities.

\section{Question Three}

What are the Vietnamese disabled individuals' attitudes toward their own disabilities and the disabilities of others?

Three main themes emerged regarding attitudes of the subjects toward their disabilities and toward the disabilities of others. These themes are: (1) "loss and self-realization," (2) "capability for a good life," and (3) "a contributing member."

\section{Loss and Self-realization}

Tôi thây như ... tôi bị như vậy là mợt cái mất mát rất lớn. Tại vì khi cái người đàn ông mà ở trong đời là có nhiêu trách nhiệm với gia đình. Nhưng mà sau khi mà tôi bị thương rồi a, thì cái trách nhiệm đó nó bị mất mát dữ lắm. . . . Cũng có nhờ cái tật nguyền này, về cái phàn đạo đức thì mình dể thương [người ta] hơn. (I think ... my 
condition is a very big loss. Because in life, a man has a lot of responsibilities to his family but after I was injured, those responsibilities suffered very much. ... It is because of this disability, in regard to humanity, it is easier for me to love [others].) Minh.

This theme emerged in all six cases. The subjects expressed feelings of loss as well as a chance to learn more about themselves in regard to their disabilities.

All of the subjects indicated that their disabilities have affected their physical stamina which makes other activities more challenging for them or prevents them from engaging in certain activities. Thuy, Mai, and Truc indicated that they must rely on the help of others if they need to carry something large or heavy. They also said that it is difficult for them to stand for a long period of time such as for dissecting in anatomy lab or while cooking. Both Huong and Mai are physically active. They expressed the frustration of having to rely on others at times due to their physical limitations. Furthermore, because of natural or structural barriers, they were unable to participate in some activities with their peers. For example, Huong expressed her disappointment of not being able to go on hiking trips with her friends at the temple.

In addition to feeling a loss of physical abilities, some subjects also feel a loss in the fulfillment of their roles. Minh and Quan considered their disability as a major loss for them, which have prevented them from fulfilling the primary role of providing for their families. With his family's love and respect, Minh has learned to accept his oldest son as the provider of 
the family. Quan's disability and the move to the U.S. had forced him to take on a new role of a caretaker in his family while his wife works out-of-home. Also because of the love and acceptance of his family, he has adapted to his new role. Both Minh and Quan shared that they continue to take on the leadership role of making decisions in the family and educating their children. This role has helped them with their self-esteem.

Aside from sensing a loss, the subjects also shared a theme of "selfrealization." They stated that their disabilities have helped them in (1) learning more about themselves and about those around them, (2) gaining emotional strength and sensitivity, and (3) developing creativity to problem solve for adaptation. Five of the six subjects expressed that their disabilities have helped them become more compassionate, more accepting, more forgiving, and to appreciate the simple things in life. Four of the subjects said their disabilities pose many challenges for them that have given them "ý chí phấn đâu" (a will to fight) and thus to develop an inner strength leading to development. Two of the subjects shared that their disabilities have made them realize the depth of their family's affection for them.

All of the subjects expressed that their disabilities have forced them to make constant adaptations during their daily lives. For example, Quan talked about figuring out how to hammer a nail into the wall with just one hand. Disability has helped them learn to become more adaptable and more creative in their problem solving skills.

\section{Capability for a Good Life}

Đây là đất của cơ hội, thành ra ở đây không có limit đới với người tàn tật . . . Thành ra . . . họ vẩn còn có được một peaceful life. ... Ve phương diện hôn nhân và nghè̀ 
nghiệp thì không có gì cản trở. Thành ra họ vẩn có được một đời sống bình thường. (This is the land of opportunities, that's why there is no limit for people with disabilities ... That's why ... they still can have a peaceful life. . . Regarding marriage and career, there are no limitations. That's why they can still have a normal life.) Thuy.

This theme is prevalent in five of the six cases. The subjects indicated that they feel people with disabilities are capable of having a good life. The definition of a good life varies among the subjects. Thuy, Mai, and Huong appeared to define a good life as being able to live independently, having a successful career and a personal life in addition to the love of their families and friends. Minh and Quan seemed to identify a good life as keeping busy with leisure activities or with household chores, and being loved and respected. They appeared to be more hesitant about the disabled persons' abilities to work outside of the home.

\section{A Contributing Member}

Kiếm cách cho nó [đứa con tàn tật] tìm phưong tiện đẻ mà học hỏi. Kiếm cái ngành, cái nghề, học chử để mà sau này nó có thể nó giúp đở cho đời của chính bản thân nó và cho xả hội. (Try to find ways to educate him [a disabled child]. Find a career, a job, an education so that later he can help himself and the society.) Minh.

In five out of six cases the theme "a contributing member" emerged regarding views about persons with disabilities. The type of contribution varies and may include helping with household chores, educating the 
children, or working to earn wages. Thuy, Mai, and Huong all expressed that they do not see many limitations in their abilities to have a successful career and be a valuable contributor to society. Mai said "We [disabled persons] can succeed, we can do things, ... we are still a member of society and that we can do good for it." For Quan and Minh, they seemed to feel that they are not a burden, but a much needed part of their families' livelihood and are contributors to the daily household activities. Both of them place considerable emphasis on guiding and educating their children.

Summary and Discussion of Question Three

According to the emergent themes, Vietnamese people with disabilities perceive themselves as having suffered a loss in their physical abilities and/or in the fulfillment of their roles. This loss posed many challenges for the disabled persons which in turn helped them to discover more about themselves and to develop new skills. The subjects also see a disabled person as having the capability to have a good life, and as being a contributing member of the family or to the society. The definition of a good life and how the contribution is made varies among the cases.

The attitudes of other people toward the persons with disabilities appear to have some influence on the disabled person's attitude toward themselves. The attitudes of loving and caring from family members or from friends appear to provide support for many of the subjects in the process of accepting their loss. With adaptation over time, the subjects came to realize many other qualities about themselves and many strive for independence and other achievements. Truc's case is an exception, however. When she moved to the United States 5 years ago, she lost her job and her friends--the two things 
that she identified as most important in raising her self-esteem. With the lack of caring attitudes from her family and the lack of close friendships here in the United States, she appears to have lower acceptance of her disability. Her goal is to overcome her "illness."

The level of independence and achievements that the subjects accomplished appear to depend on the subjects' personalities and their beliefs about the limits of their abilities. These factors influence how much the disabled persons are willing to accept their families' attitudes of protectiveness and live within the boundaries of their conservative expectations.

Thuy, Huong, and Mai are highly independent individuals . They appear to have good self-confidence and set high goals for themselves. They also describe themselves as "fighters" and believe that they can achieve anything to which they put their minds. They challenge any limitations that their families may impose upon them. Minh and Quan are also independent individuals; however, they appear to have lower confidence in their abilities to work outside of the home and thus set goals for themselves within the safer boundaries of their homes. They seem to accept their families' protectiveness more.

The attitudes of increased openness, helpfulness, and mere indifference or acceptance of the general Vietnamese public also appear to influence the subjects' perceptions regarding themselves. This influence is most evident in the case of Huong where her perception regarding her abilities and the abilities of other disabled people has changed drastically through the years, especially from the time she was in Vietnam to today. This change appears to 
be fostered by the change in attitude of her family members, the positive experiences she has with other people in the community, the social opportunities available to her, and the things she has accomplished. She now sees herself as having a good life and as a valuable contributing member of the society. Furthermore, Minh also mentioned that the more accepting attitude here in the United States has made him feel respected and allows him to live a more peaceful life.

The emergent themes indicated that the subjects' attitudes toward disabilities are generally positive. However, the researcher noted some discrepancies in few of the cases between the subjects' expressed attitudes and the subtle attitudes revealed through their comments. Minh described himself as happy, blessed, and useful. He indicated that a child with disability needs to be loved and to be educated. The child needs to take care of himself and contribute to society. Nevertheless, at another time during the interview, Minh commented that after a person is disabled, he/she should not hope for much but just find ways to entertain himself for the day to go by. Quan, on the other hand, sees himself as able and competent. He encourages persons with disabilities to fight to become independent and even appoints himself to serve as a role model. However, he refused a job offer to work as a translator and often talks about how negatively other people view persons with disabilities.

The researcher also noted some other interesting factors revealed in the study. Minh and Truc, who are recent immigrants (lived 3 years or less in the United States), appeared to have less positive attitudes toward their disabilities than the other subjects. Furthermore, Mai, Huong, and Thuy, 
who are younger ( 34 and under) and became disabled in their childhood, appeared to have confidence in their abilities to have a career outside of the home while Minh and Quan, who are older (47 and older) and became disabled in their adulthood, seemed to be more comfortable with their abilities to contribute within the boundaries of their homes and are not as motivated to work outside the home. For Minh and Quan, their lower self confidence may be partially due to the fact that their disabilities have forced them to take on roles that they may believe to be less important for males in the Vietnamese culture.

The differences discussed above indicate that factors such as chronological age, age at the time of immigration to the United States, age of onset of disability, and gender may also have influences on the attitudes of persons' with disabilities toward themselves.

\section{Question Four}

What are the motivational factors that influence the Vietnamese disabled individuals in psychosocial adjustment and self-improvement?

Four themes were defined as motivational factors for persons with disabilities for their psychosocial adjustment and self-improvement. They are (1) love from others, (2) personal needs, (3) social opportunities, and (4) role models.

\section{Love From Others}

Hởi xưa tôi có cái tự ái, cái buôn, . . ., nhiêuu khi bị tủi thân. Nhưng sau này thì không vì tôi thấy vợ con mình nó cũng kính trọng, thưong mến mình. Bởi vậy thành thử mình cũng an ủi. (I used to have a lower self-esteem, feel sad, . .., 
sometimes I felt sorry for myself. But I do not feel that way now because I see that my wife and children do respect, do love me. This is very comforting for me.) Minh.

A theme "love from others" was found in all of the six cases. Whether this love and support comes from family members or friends, the subjects see it as a motivating force for them to adjust to their disabilities and to meet the challenges in their lives. Mai indicated that despite feeling frustrated with her parents' protectiveness, she sometimes feels glad and comforted by the fact that her parents love her and care for her. Furthermore, even though she does not always agree with her parents, she feels that her parents always try to understand her needs and support her. Thuy identified the love of the family as the most important thing for a disabled person or a disabled child to develop to his/her full potential. For Minh and Quan, they were able to adjust to their new roles with the love, support, and respect from their families.

A motivating force for Truc is her friends in Vietnam. She said that they have helped her feel good about herself and have wholeheartedly helped her in the journey to get over her "sickness." For Huong, even though she described her relationship with her family currently as close and loving, she appeared to rely very much on the support of the people in the study group at the temple. She identified her interaction with these people as the major factor that changed her life. She said they made her feel included and accepted. Huong was then able to change from concentrating on her disability 
to focus more on her abilities. She learned to control her anger through Buddhist teaching and became more content with her life.

\section{Personal Needs}

I just want to succeed in whatever I do. . . Just be independent . . . I see what other people can do, I try to do it you know. . I am stubborn so if I can't do it, I want to try again. Mai.

\section{and}

Như là có một con đường sáng nào đó mà em thấy là tụi em [người tàn tật] có thể cân thiết được cho xả hội thì tựi em go on được. (It's like if there exists a promising road that we [persons with disabilities] can be helpful for the society then we can go on.) Huong.

This theme, "personal needs", is evident in all six cases. The subjects expressed a variety of individual needs, which may include feeling important, needed, respected, visible, capable, comfortable, secure, and loved. These needs appeared to be the motivational force for them to face challenges and to meet their goals. The data appeared to indicate that the subjects mainly meet these needs through independence, achievements, and being contributing members of family and/or society. Independence can include participation in leisure activities, supporting oneself financially, and performing physical activities independently. All of the subjects are independent in their daily self-help skills. Contributions can include volunteer work, being a member of the work force, running the household, or educating and/or guiding the children. 
Thuy shared that when she feels hurt or discouraged, her achievements have helped her the most in gaining back her confidence and motivated her to accomplish her goals. Mai talked about her frustration with being dependent on other people for some physical activities. One of her main goals is to find alternate ways to accomplish activities independently. Huong expressed that while growing up, she was always fearful that people would abandon her. When she came to the United States, she fought for her independence physically as well as financially. Huong now described herself as visible, important, and secure because she can now take care of herself and no longer feels fearful.

Quan talked about being important and being respected. He strived to manage the household chores independently, and to care for and educate his children. Quan stated that his family would fall apart without his support. Minh wants to keep busy so he persistently challenges his family to allow him to do gardening and to fix things around the house. Truc, whose primary goal is to overcome her "sickness", would go out on her own to therapy but does not try to go out other times by herself.

\section{Social Opportunities}

Lúc em bước qua đến bên Mỹ này thì gióng như nó give em a chance để đới diện với cuộc đời hơn. Em tháy ràng em có thể làm được tất cà mọi việc gì. Ỏ đây có đủ tất cả điều kiện để cho mình làm được. (When I came to the United States, it was like giving me a chance to face my life. I see that I can do everything. Here, there are many conditions that allow me to do them.) Huong. 
Four of six subjects mentioned social opportunities as one of the motivating factors for them. Huong mentioned several times during the interview that seeing the opportunities available to her in the United States had given her the courage to fight for her rights and for her independence. Minh, Thuy, and Truc all indicated that the United States is the land of opportunity for people with disabilities and they can do anything to which they put their minds. Therefore, people need to take advantage of these opportunities or be comforted that they will not be neglected by society.

Interestingly, Mai who came to the United States at the age of seven, expressed frustration with the fact that there are not enough laws and programs available here to assist persons with disabilities. She feels that the general American public needs to be more aware of the needs of disabled people, especially in making buildings and recreational areas more accessible for persons with disabilities.

\section{Role Models}

Những cái role model rất là quan trọng. Mînh có thể find out được những cái role model trong xả hội, thì mình cũng có thể giúp cho họ [người tàn tật] để họ vươn lên dược. (Role models are very important. We can find out about the role models within the society, then we can help them [persons with disabilities] to move forward.) Thuy.

The theme "role models" was identified by four of the total six subjects. Thuy, Mai, and Quan all felt that a successful person with disability can really help give a person motivation to strive to be better, and also to educate the general public regarding disabilities. Thuy and Mai gave examples of 
successful disabled people as respected professionals (i.e. doctors, teachers), or someone who has managed to accomplish a difficult challenge (i.e. rock climbing). Quan suggested that a role model is simply someone who has made it through the adjustment process and is able to demonstrate independence.

Huong also felt that a role model is important; however, she thinks this person needs to be non-disabled. Huong said that many people with disabilities do not want to see other disabled people because they are afraid that they will see themselves. She felt this way previously. Nevertheless, Huong shared that seeing the situations of other handicapped people has made her see that she is luckier than many, and this also has motivated her to achieve.

\section{Summary and Discussion of Question Four}

According to the emergent themes, the main motivational factors for Vietnamese persons with disabilities are 1) their own personal needs and, 2) the love of others. Many of the subjects expressed that their accomplishments are the result of their personal hopes and desires, not from the expectations of their families or of non-family members. Nevertheless, many indicated that the love of others, whether they are family members or friends, is important in that it provides support and security for them in order to meet challenges.

The subjects expressed a variety of personal needs. They appeared to try meeting these needs through independence, personal achievements, and being a contributing member of the family or of society. These factors seemed to help raise the disabled persons' self-esteem as they perceive themselves as capable and important in the lives of others. The level of independence and 
achievement, and the type of contribution attained by persons with disabilities seems to depend on their desires to accomplish a goal and perhaps on the perception of their abilities.

Minh shared that he started to perform odd jobs to help his family financially but stopped because his family does not want him to work. However, he did not give up his leisure activity of woodworking despite objections from his family. This suggests that Minh's confidence and desire for woodworking is stronger than his desire to work outside of the home. Also culturally, it is accepted if not expected that grown children take care of their elderly parents, especially when the parents are ill or disabled. Quan, who refused a job offer as a translator at his daughter's school, challenged himself to become competent at all household tasks to support his family. This suggests that Quan may feel his disability has limited his ability to work and earn money. However, he does not see himself as helpless and strive to support his family in other means. Even though Quan has relinquished his responsibility as being the "bread winner" of the family, he continues to express his leadership role in decision making and in educating his children.

Mai, Thuy, and Huong have strong desires to be independent physically as well as financially. They set many academic and physical goals for themselves, and they determine to achieve these goals despite advice against them from their family members. Truc prefers to refer to her disability as an illness that she can overcome. Truc's desire to be "healthy" motivates her to participate in therapy. She moved closer to the hospital where she receives therapy and lives on her own. She expressed that she would find ways to get to therapy but does not go anywhere else by herself. 
Seeking or using role models was also suggested to motivate a person, whether this person is disabled or non-disabled. The subjects also identified opportunities and support within society as an important factor in their struggle to accomplish their goals.

In attempting to help persons with disabilities, Huong reminded the researcher of people's individualities, that each person has different needs and desires. Before attempting to help a person with a disability, one must first take time to understand the person's styles and their motivations. 
CHAPTER 5

\section{DISCUSSION, PROFESSIONAL IMPLICATIONS, RECOMMENDATION}

\section{Introduction}

This chapter is organized into three sections. The first section presents discussion of the study's findings and the literature. The next section describes the implications for occupational therapists in practice. Limitations of the study and recommendations for future research are provided in the last section of the chapter.

\section{Discussion}

The themes "increased awareness" and "indifference or helpfulness" suggest the general attitudes of Vietnamese people toward persons with physical disabilities are more open or tolerant in the United States as compared to those in Vietnam. Vietnamese people in the United States may be more aware of the rights of disabled individuals, and consequently, learn more appropriate ways to socially interact with them. The increased awareness is attributed to (1) exposure of specific programs and laws designed to assist people with disabilities, and (2) the more open attitudes of the American public toward persons with disabilities. With heightened awareness and increased social interaction between Vietnamese disabled and 
non-disabled individuals in the United States, misconceptions are reduced and more realistic perceptions are achieved.

Three themes emerged regarding attitudes of family members toward the member with disability. They are (1) "conservative expectations," (2) "protectiveness," and (3) "attitudes of loving and caring." The participants observed changes in their families' perception about their abilities as they demonstrated their achievements. The family members adjusted their attitudes through the years to become less protective and less conservative in their expectations.

The changes in attitudes of Vietnamese people in the United States and the changes in attitudes of family members discussed above reinforce the concept that the human is an open system which interacts with and is influenced by the environment (Kielhofner \& Burke, 1985). The values and beliefs of a person are constantly being re-evaluated and reformed according to the input of the environment and the feedback of the experiences provided by that input.

For Vietnamese persons with physical disabilities, the emergent themes suggest that they expressed positive attitudes toward their own disabilities and the disabilities of others. They perceive themselves as valuable members of society living fulfilling lives. These perceptions are evident in the themes "loss and self-realization," "capability for a good life," and "a contributing member." Nevertheless, in two of the cases, the participants' expressed attitudes were noted to contradict with the more subtle attitudes revealed through their comments. This discrepancy indicates that the actual attitude of Vietnamese persons with disabilities may be less positive than the 
themes suggested. The literature noted that Vietnamese people possess a well-developed ability to keep their true feelings to themselves. Denial and avoidance are used for self-control--a traditional value to the Vietnamese people (M. D. Nguyen, 1985). Perhaps the two participants restrained themselves against what they perceive as showing weakness and attempted to share more positive emotions about themselves with the researcher, who was a stranger to them.

The main motivational factor for persons with disabilities revealed in this study is "personal needs." Personal needs may include feeling important, needed, respected, visible, capable, competent, comfortable, secure, and loved. These needs are outlined in the literature regarding human needs and motivation. Deci and Ryan (1985), and Kielhofner and Burke (1985) talked about the human needs to explore and master the environment, and Maslow (1970) describes the human hierarchy of basic needs--physiological, safety, love, esteem, and self-actualization--as the motivational forces of human behavior. The participants indicated that it is their own internal drive to meet personal needs, which may be related to Maslow's love, esteem, and self-actualization needs, that motivates them to overcome challenges and to achieve. The family's conservative expectations and protectiveness may have hindered them, but did not prevent them from trying to accomplish their goals.

The data also suggested love and caring as being important for the disabled individuals. Love and caring of others provide a good foundation--a stable and secure environment--for the disabled persons to follow their internal drives, conquer life challenges, and achieve. This is expressed in the theme 
"lo:e from others" in motivational factors. Maslow (1970) identifies belonging and love needs, and esteem needs as some of the basic needs to be satisfied before self-actualization.

Other motivational factors identified in this study for persons with disabilities are "social opportunities" and "role models." The opportunities that are available to persons with disabilities in the United States were identified as one of the factors that gave Vietnamese persons with disabilities the forum to rise and challenge their own as well as others' cultural misconceptions. Instead of taking on the ignored and passive roles, they strive to achieve, become independent, and be valuable contributors to their families and to society. Furthermore, successful persons with disabilities in the society can serve as role models for disabled individuals to strive toward in their journey for self-improvement.

In comparing the results of this study to the available literature regarding attitudes of Asians toward persons with disabilities, few similarities were found. One theme, "lacking understanding," is somewhat consistent with the literature. Chan (1976) discussed the Asian's misconceptions about persons with disabilities as being maladjusted, having unsound minds, and living unfulfilled lives. These misconceptions have led many youngsters to behave "cruelly, lacking sympathy, empathy, and understanding" toward the person with disabilities and for society to ignore them (p.14). Five of the participants expressed the lack of understanding on the part of Vietnamese people living in Vietnam regarding disabilities. Three of the participants described similar experiences of being cruelly treated by youngsters in their 
community in Vietnam. None of the participants identified the "lack of understanding" attitude from Vietnamese people living in the United States.

A belief that disability is a consequence or punishment for sins committed in a previous life is well documented in the literature (Chan, 1976; Chan, 1986; Morrow, 1987). This belief results in creating considerable stigma, shame, and embarassment for the disabled persons and their families. Only one of the participants, Minh, voiced the belief that disability is the consequence of punishment for sins committed by the individual, the individual's parents, or ancestors. When the researcher asked Minh how a disabled person should be treated in relation to this belief of "punishment for past sins", he replied that the person should be treated with much love and sympathy. He felt this might alleviate some of the family's as well as the disabled person's sufferings, and perhaps help the disabled person have a better life in his/her next life.

Huong, another participant who is also actively involved with the Buddhist temple and studies Buddhism, did not mention the religious belief of "punishment for past sins." Interestingly, she credited her study of Buddhism and her participation with the Buddhist temple for achieving selfactualization. She indicated that she has learned to be patient, to live in harmony with others, and to be at peace with herself. These new understandings guided her to develop better relations with her family members and to control her anger, thus allowing her to begin exploring her potential. Huong indicated that above all, the love, caring, and respect from the members of her temple serve as a main motivational force for selfimprovement. 
Religious beliefs may place predispositions on people's perceptions and thus somewhat influence their attitudes toward disabilities. However, people also appear to intepret and apply their religious beliefs according to what works for them. For example, Thuy who is Catholic believes a disabled child is a gift from God while Minh who is Buddhist believes that a disabled child is an unfortunate consequence of past sins. Thuy views the disabled child as a positive consequence where Minh views the disabled child as a negative consequence. Nevertheless, both express the same treatment toward the child with disability which is characterized by love, kindness, and support. Minh and Huong appeared to apply the positive characteristics of Buddhist teaching such as perseverance, unconditional kindness, and empathy in dealing with their disabilities and the disabilities of others. They view disabilities as sufferings, but if treated with patience and kindness, the sufferings are lessened and peace can be attained. Perhaps, with the knowledge that no one is free from the possibility of this punishment, some people are motivated to treat people with disabilities with compassion rather than cruelty. Furthermore, eastern religions such as Buddhism, Confucianism, and Taoism may become adapted to meet the broader acceptance of disability in the United States.

Another documented attitude of Asians in the literature is interdependence. Ruddock (1992) stated that the Asian value of interdependence has an effect on therapy goals. She suggested enabling a disabled person to function more independently may not be a goal if, culturally, it is the family's responsibility to care for the person and there is no value placed on independence. According to the findings of this study, the 
subjects who are Vietnamese persons with disabilities place a great deal of value on independence, achievement, and being a contributing member of the family and of society. These values are evidenced in the themes "a contributing member" and "capable of a good life" in regard to the disabled persons concept of disability. Independence, achievement, and contribution are factors that enable persons with disabilities to meet their personal needs and thus develop a more positive self-concept. Furthermore, the subjects indicated that their accomplishments have helped change their families' attitudes toward their abilities.

Strong family bonds and obligations are evidenced in the results of this study. These findings are consistent with the literature regarding the Vietnamese family unit and family values. Each family member is viewed as an integral part of the totality of the family and members are taught to think of the family first (M. D. Nguyen, 1985; Vuong, 1987). Family members may feel responsible to provide for the member with disability and the disabled member may feel obligated to accept the help of his/her family.

The results of this study have generated some interesting information regarding Vietnamese attitudes toward other Vietnamese persons with physical disabilities. However, these attitudes can not be generalized to the entire Vietnamese population in the United States due to the small sample size of the study and the large number of variances. These variances may include the participants' gender, chronological age, residence in Vietnam, age upon entering United States, length of time living in the United States, and level of disability. In general, the attitudes found in this study are more positive than those documented in the literature. This may be attributed to 
the level of assimilation of the participants to the American culture and to the fact that the majority of the them came from urban regions in Vietnam where the people may have less superstitious beliefs regarding the cause of disabilities.

\section{Implications for the Profession}

Occupational therapy holds as one of its basic tenets the principle that each person must be viewed holistically. Thus, in treating individuals with physical disabilities, physical as well as psychosocial and environmental components must be considered.

Treatment begins with assessment. In addition to obtaining information about the patients' motor abilities and needs, occupational therapy assessment must also explore the patients' environment, values, and interests. This information will provide the therapist with a structure to understand the patients--to understand what motivates them and the activities that are meaningful for them. The therapist can then set up appropriate therapeutic environments and develop goals that are valuable to the patients, thus maximizing the benefit of therapy.

According to the findings in this study, environment plays an important role in shaping people's views of disabilities. Disabled persons' attitudes about themselves change as their environment changes. With the more open attitudes and exposure to social programs in the United States, Vietnamese persons with disabilities develop increased self-worth and strive for self-improvement. Achievements bring them new expectations regarding 
their effectiveness in the environment. These expectations influence the degree of challenge that they are willing to seek. With new attitudes, the persons' actions are altered influencing the attitudes of family members and possibly bringing a change in the actions of the family members. The disabled person both shapes and is shaped by the environment. Naturally, in order to treat the person holistically and effectively, therapists will need to consider the patients' environment (structure, social, as well as cultural) when assessing them.

Kielhofner and Burke (1985) identify culture as an environmental layer which prescribes the meaning of work and play activities. It is an important factor that determines people's values and interests. Cultural background is a history of environmental interactions that contributes to people's lifestyles and their perceptions of disability. It affects the way they operate within and respond to therapy. Attempts to understand a person's behavior will not be complete without some understanding of the culture from which the person came and the behavior patterns that were encouraged and discouraged by that culture. Occupational therapy is valued only if patients believe that they have been helped by it. Chances are therapists who are capable of attending to the patient's cultural values by selecting relevant treatment activities are also able to convince the patient that therapy is important, deserving their interest and cooperation.

Findings of this study suggest variances such as chronological age, age at time of immigration to the United States, age of onset of disability, length of stay in the United States, and place of residence in Vietnam may influence persons' perception of disability. Therapists will need to consider these 
variances when applying cultural knowledge in assessment and planning treatment.

The aim of occupational therapy is to create rich and safe environments for patients' exploration, competence, and achievement--the levels of function described by Kielhofner and Burke (1985). In the treatment of Vietnamese patients, therapists need to be aware of certain cultural attitudes and values regarding disabilities that might have an impact on the patients' participation in therapy. This heightened awareness will foster the development of rapport and enable the therapist to create an appropriate therapeutic environment that facilitates the patients' adaptation. A sensitive therapist will respect the patient's cultural values and beliefs; however, if the therapist feels that the culturally defined problems are impeding the therapeutic process, he/she can help the patients and their families toward reformulating the role of the disabled person. For example, according to the needs and values found in the assessment, the therapist can plan meaningful, motivating activities for the patients and elicit performances. Successful outcomes in turn give positive feedback to modify any negative perceptions held by the patients and their families.

Cultural sensitivity is highly recommended in treatment and respect toward the patient's individuality is a must. Therapists need to be careful not to generalize all of their Vietnamese patients and categorize their behaviors within cultural stereotypes. For example, the therapist should not automatically interpret non-motivated behavior of Vietnamese patients' as the result of the common cultural value of interdependency without exploring other possible causes. 
The findings of this study suggest that Vietnamese persons with disabilities do value independence. They have needs to be competent, to achieve, and to contribute. They may feel obligated to accept certain assistance from their family members and may appear non-motivated initially; however, they are also capable of confronting challenges in order to achieve goals that are meaningful to them within a supporting environment. One of the main motivating factors for Vietnamese persons with disabilities revealed in this study is personal needs. These needs appear to be more powerful than family expectations regarding goal accomplishment. The therapist will need to explore the patients' values and needs to set treatment goals that are motivating for them. As the patients demonstrate competence, the family's perception regarding the needs of the disabled member may change. The family perhaps will modify what they feel that they are obligated to provide. The therapist then must explore before and during treatment the needs of the patients through interviews and observations. With information about the patients' needs, the therapist can then make decisions about the focus of therapy and how to motivate the patients.

According to the results of this study, Vietnamese persons with disabilities identify the love of their family as a strong motivating factor for them. This love provides safety and security for them, and enables them to conquer challenges. Five of the six subjects indicated strong bonds with their families. Felice (1986) and M. D. Nguyen (1985) indicate that in Asian cultures, the entire family is usually involved in making health care decisions for a family member. The above facts indicate that even though the therapist's focus 
must be on the Vietnamese patients' individual needs, he/she also needs to be aware of the importance in involving the family in treatment.

Other motivating factors found in the study for Vietnamese persons with disabilities are social opportunities and role models. A therapist may want to help the patients become more aware of the available resources and to use role models as appropriate in treatment.

In summary, therapists must view their patients holistically in order to successfully treat them. Assessment should include information regarding the patients' physical needs and abilities, their values and interests, and their environment. Culture is an important part of the environment which defines lifestyles, values held by patients, meanings of activities, and perceptions about disabilities. Therefore, cultural sensitivity is needed in order for therapists to develop effective therapeutic environments. Therapists should be cautioned not to place their Vietnamese patients within cultural stereotypes and narrowly interpret their behaviors. Motivational factors of Vietnamese patients need to be explored so that therapists can successfully elicit performance. The results of this study indicate that Vietnamese persons with disabilities have strong bonds with their families; however, they are willing to challenge their families' attitudes in order to achieve goals that are important to them. In working with Vietnamese clients, the therapist need to involve the family in the treatment process while not losing focus on the patients' personal needs and desires. 


\section{Recommendations}

Supporting the need for this study is the lack of information about Vietnamese attitudes regarding disabilities, the importance of attitudes in psychosocial adjustment, and the growing number of Vietnamese people living in the United States. This study was an attempt to heighten cultural awareness of professionals who may work with Vietnamese clients, and specifically, of occupational therapists. The researcher recommends further study to be made in this area to substantiate or challenge the findings of this study.

Since the focus was to explore emerging issues regarding attitudes of Vietnamese toward persons with physical disabilities, this study used the open-ended interview methodology. However, because of this structure of interview, the interviewer was not able to ask questions regarding issues that had not emerged, thus relating the literature to the discussion of the findings was difficult. Suggestions for future study include modification of the study design. Future studies could employ a more structured interview method designed to answer specific questions regarding issues of concern. This may help to provide more specific information directly relating to occupational therapy in practice.

Furthermore, if possible, a larger randomized sample size is suggested. The results could then be generalized to the general Vietnamese population, and comparisons could be made between different groups of the people within the sample. The groups might be organized according to charactersistics such as present age, age upon immigration, age of onset of 
disability, urban/rural residence in Vietnam, length of time in United States, type of disability, religion, and gender.

This study examined Vietnamese attitudes as perceived by Vietnamese individuals with physical disabilities. Future researchers could take a further look at the actual attitudes of family and non-family members, and perhaps make comparisons with the attitudes perceived by the disabled persons. Effort could also focus on a selected group of Vietnamese people such as recent immigrants or specific disabling conditions. Other cultural perceptions that might be useful to explore are (1) perceptions of Vietnamese patients regarding occupational therapy services in rehabilitation, (2) perceptions of Vietnamese patients regarding independence and valued activities of different age groups, and (3) perceptions of Vietnamese parents of disabled children regarding occupational therapy services (in early intervention, in the school system, or in the medical setting). Pediatric therapy under the educational model often requires the parents to participate as team member in the planning of their child's treatment program. This requirement is conflicting with the Asian cultural belief that health professionals are the experts who should provide specific answers and recommendations (Muecke, 1983). The family may be confused and/or may develop distrusting feelings toward the professionals involved.

Future researchers can also take a look at how therapists can successfully involve the Vietnamese family and how to deal with the family's protectiveness in conflict with the traditional therapeutic goal of independence. Furthermore, it would be useful to assess the needs of Vietnamese clients and their families. This information is necessary in 
planning health programs and in increasing follow through in therapy treatments.

In securing subjects for this study, the researcher experienced much difficulty despite the fact that she is Vietnamese and speaks the language fluently. Cultural beliefs of keeping personal affairs private within the family and the lack of trust toward strangers are the probable factors that contributed to this problem. Suggestions for securing participants include using "third party" persons. These persons can be religious leaders, friends or relatives, or credible professionals in the community who are trusted by the disabled persons and/or their families. By using "third party" persons, the researcher was able to establish an initial trust with the disabled individuals and their families and subsequently, obtain agreement to participate in the study. 


\section{References}

Beail, N. (1983). Physical disability: The self and the stereotype. International Lournal of Rehabilitation Research, 6, 56-57.

Burton, G. (1985). Psychosocial aspects and adjustment during various phases of a neurological disability. In D. A. Umphred (Ed.), Neurological Rehabilitation (pp. 118-133). St. Louis, Missouri: C. V. Mosby.

Chan, D. C. (1976). Asian-American handicapped people: an area of concern. Lournal of Rehabilitation $\underline{42}$ (6), 14-15, 49.

Chan, S. (1986). Parents of exceptional asian children. In Kitano \& Chinn (Ed.), Exceptional Asian Children and Youth (pp. 36-53). Virginia: The Council for Exceptional Children.

Cohon, J. D. Jr. (1983). Southeast Asian refugees and school health personnel. Lournal of School Health, February, 151-158.

Congbalay, D. (1988). California: Refugee magnet. San Jose Mercury News. p. 1.

Deci, E. L. \& Ryan, R. M. (1985). Intrinsic motivation and self-determination in human behavior. New York: Plenum Press.

Dung, T. N. (1984, March-April). Understanding Asian families: a Vietnamese perspective. Children Today, (pp. 10-12).

Eliade, M. (Ed.). (1987). The encyclopedia of religion (pp. 430-450). New York, Macmillan Publishing Co.

Felice, M. E. (1986). Reflections on caring for Indochinese children and youths. Lournal of Developmental and Behavioral Pediatrics, Z, 124-128. 
Gee, F. D. (1987). Attitudes of bay area chinese-americans toward the stroke impaired. Unpublished master's thesis, San Jose State University, San Jose, CA.

Harvey, D. \& Greenway, P. (1982). How parent attitudes and emotional reactions affect their handicapped child's self-concept. Psychological Medicine, 12, 357-370.

Kielhofner, G. \& Burke, J. P. (1985). A model of human occupation: Theory and application. Baltimore: Williams \& Wilkens.

Levine, R. E. (1987). Culture: A factor influencing the outcomes of occupational therapy. Occupational Therapy in Health Care, 4, 3-16.

Livneh, H. (1982). On the origins of negative attitudes toward people with disabilities. Rehabilitation Literature, $\underline{43}$ (1), 338-345.

MacGugan, K. W. (1980). East/west attitudes toward the handicapped and their presence in postsecondary education in hawaii. Unpublished doctoral dissertation, Nova University, Hawaii.

Maslow, A. H. (1970). Motivation and personality (3rd. ed.). New York: Harper \& Row Publishers.

Morrow, R. D. (1987). Cultural differences--be aware! Academic Therapy, 23, 144-149.

Morrow, R. D. \& McBride, H. J. (1988). Considerations for educators in working with southeast asian children and their families. U.S. Department of Education. Educational Resources Information Center. (ERIC Document Reproduction Service No. ED 299 730) 
Muecke, M. A. (1983). In search of healers--Southeast Asian refugees in the American health care system. The Western Journal of Medicine, 139, 835-840.

Muecke, M. A. (1983). Caring for Southeast Asian refugee patients in the USA. American Journal of Public Health, 73 , 431-38.

Nguyen, D. L. (1985, March). Indochinese cross-cultural adjustment and communication. In Dao \& Grossman, Report of Meeting Held at the Annual Conference of the National Association for Southeast Asian Students with Special Needs. (Available from the Division of Special Education and Rehabilitation, San Jose State University, One Washington Square, San Jose, CA. 95192)

Nguyen, M. D. (1985). Cultural shock--A review of Vietnamese culture and its concepts of Health and Disease. The Western Lournal of Medicine, 142, 409-412.

Patton, M. Q. (1987). How to use qualitative methods in evaluation. New Bury Park: Sage Publications.

Pedretti, L. W. (1990). Psychosocial aspects of physical dysfunction. In L. W. Pedretti and B. Zoltan (3rd ed.), Occupational therapy: Practice skills for physical dysfunction (pp. 8-39). Missouri: Mosby Company.

Reed, K. L. (1986). Models of practice in occupational therapy. Baltimore: William \& Wilkins.

Ruddock, L. A. (1992, April). Differing cultural patterns require new approaches. Advance for Occupational Therapists, pp. 34. 
Stearns, D. (1988). Vietnamese perspectives on independence and role fulfillment in the disabled. Unpublished master's thesis, San Jose State University, San Jose, CA.

Taylor, S. J. \& Bogdan, R. (1984). Introduction to qualitative research methods: The search for meanings (2nd ed.). New York: John Wiley \& Sons.

Vuong, J. T. (1987). Vietnamese cross-cultural adjustment. U.S. Department of Education. Educational Resources Information Center. (ERIC Document Reproduction Service No. ED 286 977)

Versluys, H. P. (1983). Psychosocial adjustment to physical disability. In C. A. Trombly (Ed.), Occupational therapy for physical dysfunction (pp. 4-37). Baltimore: Wiliams \& Wilkins.

West, B. E. (1983). The new arrivals from Southeast Asia: Getting to know them. Childhood Education, 66 (2), 84-89. 


\section{APPENDIX A}

Interview Questions 


\section{GUIDELINE FOR INTERVIEWS}

\section{General Information:}

First, I would like to get to know you. Could you share with me a little bit about yourself? (i.e. birth place, education, age, marital status, work, etc.)

Please describe your family? (immediate and extended, if applicable)

What is your present living arrangement? Who are the members of your household?

Can you share with me the nature of your disability?

Please share with me what is a typical weekday and a typical weekend for you?

Where would you go by yourself? Where would you not? What are the factors that are holding you back?

What daily activities do you enjoy most? What activities do you need assistance with?

Who is the person(s) that is closest to you? What is your main supporting system? (physically and emotionally)

\section{Self-concept, Personal Goals and Motivation:}

What things do you consider as most important to you in your life? What do you want most to achieve?

Do you feel your disability has or has not affected you in attaining these?

What do you see as some of your strengths? weaknesses?

What are your expectations for yourself? How do you see yourself 5 years from now?

What are your beliefs toward disability in general?

How would you describe yourself? 
Would the person who is closest to you describe you similarly or differently?

What are 1-2 things relating to your disability that stand(s) out the most for you?

Describe the most positive experience you have relating to your disability and how it has affected you?

Experiences with Family Members:

What are the expectations that you feel your family (spouse, parents, siblings, etc.) have for you?

What do you think your disability meant to your family and how has it affected them?

What are your family's attitudes (spouse, parents, siblings, etc.) toward you and your disability? Have you seen any changes in these attitudes through the years?

How do you think these attitudes toward you have shaped the way you are today?

How would your family describe you?

Experiences with Non-family Members:

What are your Vietnamese friends' or co-workers' attitudes toward you? Do you see differences in attitude from someone who knows you longer vs someone who has known you for only a short time?

What do you think a Vietnamese person who does not know you sees you? What are some of the personal experiences that you have regarding their behavior (positive or negative) toward you?

How do you think these attitudes have affected you?

How do you think a Vietnamese friend or a Vietnamese person that you know (i.e. a co-worker) describes you? 


\section{Community Resources:}

Are you a member of any organizations for persons with disabilities? Do you utilize any of the resources available for persons with disabilities in the community?

What community resources (existing and non-existing) do you think are helpful for Vietnamese persons with disability?

What do you think you and others can do to maintain the positive or to change the negative attitudes regarding disabilities?

Do you have anything to add that we have not yet discussed? 


\section{APPENDIX B}

Consent for Participation on the Study (English) 
College of Applled Sciences and Arts - Departmem of Oceupational Therapy

One Wasningron Square - San Jose. Califorma 95192-0059

Man Otfice: 408924-3070 - Fieldwork Otfics: 408/9243078 - FAX: 408/9243088

You are invited to participate in a study that explores the attitudes of Vietnamese toward persons with physcial disabilities. The researcher hopes to gain understanding about how you perceive other Vietnamese people regard persons with disability. Your participation will supply valuable information for the health care providers who serve the Vietnamese people. If you decide to participate, you will be contacted by the researcher to set up a time and place for a one hour interview session.

The results of this study will be submitted in a thesis to the Graduate Studies and Occupational Therapy department at San Jose State University; however, any information obtained in this study that can be identified with you will remain confidential; it will be disclosed only by your permission or as required by law.

If you have any questions concerning your participation in this study, please contact Phuong-Trang Phan at (510) 783-7268. She will be glad to answer them. Questions or complaints about the procedure may be presented to Dr. Lela Llorens (Thesis Advisor and Deparment Chair, Occupational Therapy) at (408) 924-3070. For questions or complaints about research subject's rights, contact Dr. Serena Stanford (Associate Academic Vice President for Graduate Studies and Research) at (408) 924-2480. If you decide to participate, you are free to withdraw your consent and to discontinue participation at any time without penalty.

YOUR SIGNATURE INDICATES THAT YOU HAVE DECIDED TO PARTICIPATE HAVING READ THE ABOVE INFORMATION. 


\section{APPENDIX C}

Consent for Participation in the Study (Vietnamese) 
Qúy-Vị đauợc mời tham dụ một Chương-Trīnh Nghiên-Cứu về quan-niệm cưa người Việt-Nam đối với nhiưng ngưới có tật nguyên. Ngưởi chù trương việc nghiến cứu này hy vọng sể tịm hiêu được câm nghỉ cưa Qúy-Vị về quanniệm noi trên đây. Sự tham gia của Qúy-Vị sể cung cấp nhiều dự-kiện có giá trị cho các tố chúc y-tế về sức khóe đang phục vụ dồng bào Viết-Nam. Nếu Quý-Vi chấp thuận tham dự chương trinh nầy, ban sưu tấm sể tểp xúc với Quý-Vị để ấn địinh một buối đàm thoại khoang một tiếng đồng hố.

Két quá cúa chương trīh sưu tầm này sê là thành phân cửa một luận-án tốt nghiệp vê ngành "Ọccupational Therapy" tại San Jose State University. Tài

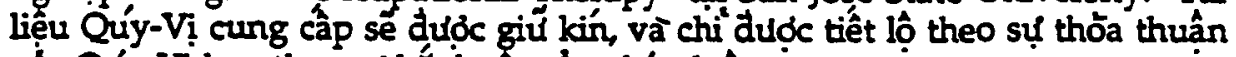
của Qứy-Vị hay theo sự bắt buột cưa pháp luật.

Nếu Qúy-Vị cần biết thêm chi tiêt về sự tham gia vào chương trinh sưu tân này, xin liên lạ với Có Phương Trang, điện thọai số (510) 783-7268, dê được giải đáp rõ räng. Vấn đề liên hệ đến thư tục xîn tiếp xúc Bà Lela Llorens (Thesis Advisor and Department Chair, Occupational Therapy), diện thọai số (408) 924-3070. Bà Serena Stanford (Associate Academic Vice President for Graduate Studies and research), điện thọai sô (408) 924-2480,sẽ giái đáp Qúy-Vị về vân đề quyển hạn liển quan đền chương trị̂h sưu tấn này. Sau khi đầ châp thuận tham gia vào chương trì̀h sưu tấm này, nếu Qúy-Vị không muốn tiép tục thi có thể yêu cầu hưy bố bất cú lúc nào, và không bị bối thương gi cá.

Chữ ký cừa Qúy-Vị dứói đây xác shận Qúy-Vị đã đọc tài liệu ghi trên, và thơa thuận tham gia vào chuoong trìn sưu tâm này. 